\title{
Gladius-bearing coleoids from the Upper Cretaceous Lebanese Lagerstätten: diversity, morphology, and phylogenetic implications
}

\author{
Romain Jattiot, ${ }^{1,2}$ Arnaud Brayard, ${ }^{1}$ Emmanuel Fara, ${ }^{1}$ and Sylvain Charbonnier ${ }^{3}$ \\ ${ }^{1}$ UMR CNRS 6282 Biogéosciences, Université de Bourgogne, 6 Boulevard Gabriel, F-21000, Dijon, France; 〈romain.jattiot@pim.uzh.ch〉, \\ 〈arnaud.brayard@u-bourgogne.fr〉,〈emmanuel.fara@u-bourgogne.fr $\rangle$ \\ ${ }^{2}$ Paläontologisches Institut und Museum, Universität Zürich, Karl-Schmid Strasse 4, CH-8006 Zürich, Switzerland \\ ${ }^{3}$ Muséum national d'Histoire naturelle, Département Histoire de la Terre, CP38, UMR 7207 CR2P CNRS-MNHN-UPMC, 8 rue Buffon, 75005 \\ Paris, France, 〈scharbonnier@mnhn.fr〉
}

\begin{abstract}
Gladius-bearing coleoids are rare in the fossil record. For the Cretaceous period, these cephalopods are mainly recorded in a few Lagerstätten in Lebanon (Haqel, Hajoula, En Nammoura, and Sahel Aalma). Here, we study 16 specimens of gladius-bearing coleoids from these Upper Cretaceous Lebanese Lagerstätten to investigate their taxonomic diversity. Besides two species that were already reported (Dorateuthis syriaca and Glyphiteuthis libanotica), one new species is identified in the Cenomanian site of Hajoula: Rachiteuthis acutali $\mathrm{n}$. sp., as well as another form of Glyphiteuthis from En Nammoura. Several studied specimens exhibit well-preserved soft-part characters. Among them, we document for the first time two transverse rows of sessile suckers in D. syriaca and we confirm the absence of tentacles, as well as the presence of a crop in this species. This strongly supports the phylogenetic proximity of $D$. syriaca with modern vampyropods rather than with modern decabrachians. In turn, the similarity in gladius morphology between this taxon and modern squids is regarded as convergent.
\end{abstract}

\section{Introduction}

The Cephalopoda Cuvier, 1797 is a large class of molluscs, representing more than 700 species, divided into two extant subclasses: the Nautiloidea Agassiz, 1847 and the Coleoidea Bather, 1888 (Sweeney and Roper, 1998), and one extinct subclass, the Ammonoidea Zittel, 884. Coleoid cephalopods differ from nautiloids mostly through the internalization (or complete loss) of the shell (Teichert, 1988). Within the cohort Neocoleoidea Haas, 1997 the shell is often called the gladius and consists of a sturdy but flexible chitinous structure within the dorsal mantle (Fuchs and Weis, 2009). The cohort Neocoleoidea is subdivided into two superorders according to the number of arms: the Vampyropoda Boletzky, 1992 (eight-armed coleoids), presently represented by octopods and vampire squids, and the Decabrachia Boettger, 1952 (ten-armed coleoids), represented by squids, cuttlefishes, and their relatives (Fig. 1). The evolutionary history of modern decabrachians and vampyropods is currently highly debated (Fuchs et al., 2003, 2012; Haas, 2003; Fuchs, 2006a; Fuchs and Larson, 2011a, 2011b; Arkhipkin et al., 2012), as is the status of the clade Neocoleoidea (Fuchs et al., 2010b). The first unequivocal evidence of vampyropod coleoids comes from the Upper Cretaceous Lebanese Lagerstätten that yielded taxa such as Palaeoctopus newboldi Woodward, 1896 and Keuppia levante Fuchs et al., 2009. However, based on molecular clock analyses, Kröger et al. (2011) suggested a Permian divergence ( 276 Ma) between the superorders Vampyropoda and Decabrachia. This estimated divergence date is thus considerably older than paleontological estimates based on scarce, but well-preserved fossil coleoids. The fossil record of these essentially soft-bodied organisms thus provides little information on the origin and phylogenetic relationships of the extant clades (Strugnell et al., 2005, 2006).

To better constrain the origin and divergence of modern decabrachians and vampyropods, a few paleontologists are currently working on Mesozoic gladius-bearing coleoids. On the one hand, some authors suggest vampyropod affinities for Mesozoic gladius-bearing coleoids that apparently never exhibit more than eight arms (Fuchs and Larson, 2011a, 2011b). On the other hand, Young et al. (1998), Vecchione et al. (1999), Bizikov (2008), and Donovan and Strugnell (2010) hypothesized decabrachian affinities, explaining the absence of ten-armed Mesozoic gladius-bearing coleoids by poor preservation or by the possibility for these organisms to retract their tentacles into pockets like some modern coleoids.

Among Mesozoic gladius-bearing coleoids, three different morphotypes of gladius can be recognized: prototeuthidid, loligosepiid and teudopseid (Fuchs, 2009). Each of these morphotypes is associated to a suborder, respectively Prototeuthidina Naef, 1921; Loligosepiina Jeletzky, 1965; and Teudopseina Starobogatov, 1983 (Fig. 1). Although the phylogenetic relationships of these three suborders with modern vampyropods and decabrachians are still uncertain, the overall gladius morphology is remarkably uniform among them. This is in contrast to the extremely high morphological diversity of modern gladii (Toll, 1998).

Most fossils of Mesozoic gladius-bearing coleoids are reported from a few localities and only rare geological horizons 
were peculiarly favourable to their preservation (Donovan, 1977). Their study is indeed limited to Lagerstätten such as the Lower Jurassic Posidonian Shales of Holzmaden (Germany), the Middle Jurassic of La Voulte-sur-Rhône (France), the Upper Jurassic of Christian Malford (UK), Solnhofen and Nusplingen Plattenkalks (Germany), and the Upper Cretaceous Lebanese Lagerstätten (e.g., Fuchs and Weis, 2008; Charbonnier, 2009; Wilby et al., 2004; Fuchs et al. 2007a; Fuchs and Larson, 2011a, 2011 b; respectively). The Lebanese Lagerstätten (essentially the sites of Haqel, Hajoula, En Nammoura, and Sahel Aalma) are the unique source of fossil coleoids with soft parts for the entire Cretaceous period (Fuchs and Weis, 2009) and 14 species are currently known. These sites yielded exceptionally wellpreserved gladius-bearing coleoids belonging to the suborders Teudopseina and Prototeuthidina (Fuchs and Larson, 2011a, 2011b) and the occasional preservation of soft parts proves useful for phylogenetic and paleobiological inferences. Unfortunately, the site of Sahel Aalma is not accessible anymore because the

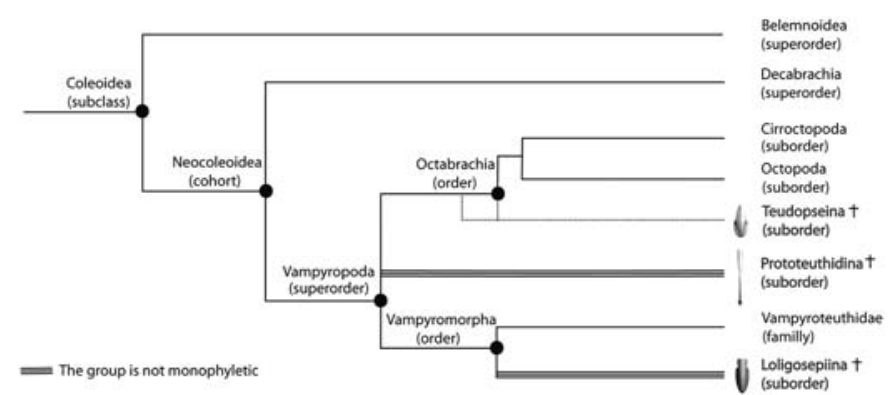

Figure 1. Phylogenetic hypothesis for coleoids considering that Mesozoic gladius-bearing coleoids (in grey and bold) are related to the eight-armed coleoids (superorder Vampyropoda). In a Decabrachian hypothesis, they would be placed in the superorder Decabrachia. Phylogenetic hypothesis modified after the Tree of Life website (http://www.tolweb.org) and after Fuchs (2009) and Fuchs and Larson (2011a, 2011b). Sketches after Fuchs (2009) and Fuchs and Larson (2011a, 2011b). fossiliferous layers are now covered with buildings. Therefore, only a few coleoid specimens have been described from this site in contrast with the high number of specimens sampled and described from the Haqel and Hajoula localities (Fuchs et al., 2009; Fuchs and Larson, 2011a, 2011b).

The original study by Roger (1946) on Sahel Aalma included some of the rare coleoid specimens and it revealed the presence of only three species at this site: Dorateuthis syriaca Woodward, 1883, "Geoteuthis sahel-almae (Fraas) (Naef)" that Fuchs and Larson (2011a) presumed to be identical to Boreopeltis smithi Fuchs and Larson, 2011a and Palaeoctopus newboldi. However, part of the Dubertret collection from Sahel Aalma, currently stored at the Muséum national d'Histoire naturelle, Paris (MNHN), has remained unstudied and has never been illustrated. These specimens certainly represent the ultimate undescribed material from Sahel Aalma. Additional MNHN specimens from Haqel, Hajoula, and En Nammoura were also included in this study.

The present work focuses on these remarkable paleontological samples and it addresses the following questions: (1) What is the overall gladius-bearing coleoid taxonomic diversity recorded for the Upper Cretaceous Lebanese Lagerstätten? (2) Can these specimens help to reconsider the paleobiological signal carried by some anatomical characters, especially those based on soft tissues? (3) Because current debates mainly focus on the phylogenetic affinities of gladius-bearing coleoids, are the Cretaceous taxa of this group related to modern vampyropods or to modern decabrachians? What characters could be used to disentangle this phylogenetic conundrum?

\section{Geological setting}

The Upper Cretaceous Lebanese Lagerstätten are mostly represented by four famous localities: Haqel, Hajoula, En Nammoura, and Sahel Aalma (Fig. 2). These "fish-shales"
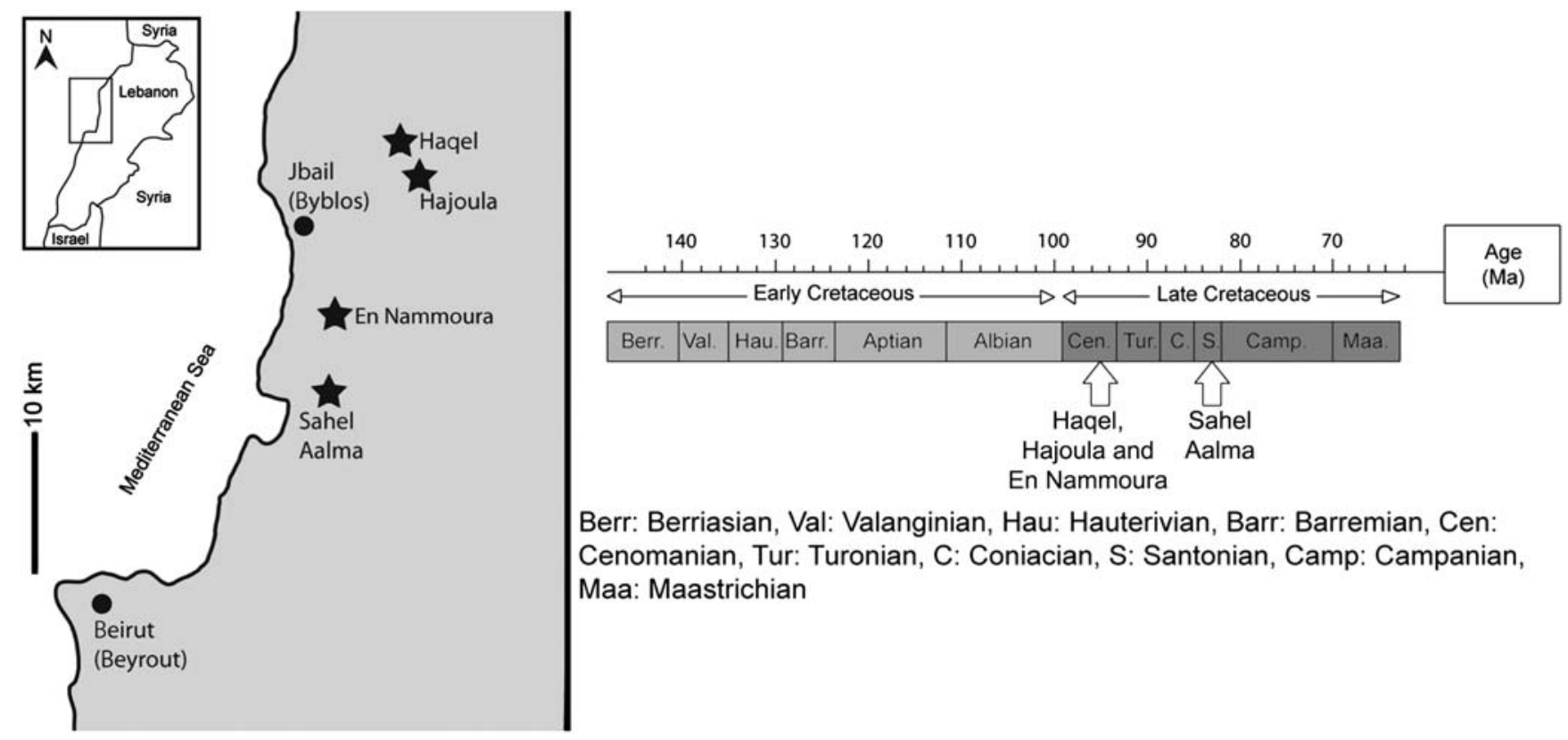

Berr: Berriasian, Val: Valanginian, Hau: Hauterivian, Barr: Barremian, Cen: Cenomanian, Tur: Turonian, C: Coniacian, S: Santonian, Camp: Campanian, Maa: Maastrichian

Figure 2. Geographic location of Haqel, Hajoula, En Nammoura and Sahel Aalma (modified from Fuchs and Weis, 2009) and their stratigraphic position. 
(Lukeneder and Harzhauser, 2004) yielded a large number of well-preserved cephalopods (Fuchs and Larson, 2011a, 2011b), crustaceans (Audo and Charbonnier, 2013), and fishes (Gayet, 1980). Haqel, Hajoula, and En Nammoura are late Cenomanian in age (Forey et al., 2003), whereas foraminiferans indicate a late Santonian age for Sahel Aalma ( 85 Ma; Ejel and Dubertret, 1966; Fig. 2). Meister (1993) reported the ammonites Muniericeras blanfordianum Stoliczka, 1865 and Texanites texanus Roemer, 1852, which corroborates a Santonian age for this site. Ten unreported ammonites from the MNHN Dubertret collection were also identified as T. texanus and M. blanfordianum, thus further supporting a Santonian age for Sahel Aalma.

Detailed sedimentological descriptions of the Lebanese Lagerstätten were provided by Audo and Charbonnier (2013). During the Cretaceous, Lebanon and the entire Arabian Peninsula were located on the African platform in the northern part of Gondwana (Philip et al., 1993). The lithographic limestones from the Hajoula, Haqel, and En Nammoura Lagerstätten were probably deposited in small shallow basins corresponding to intra-shelf depressions. In this scenario, mild oscillations in relative sea-level were responsible of a spectacular sandwich of shallow-water carbonate facies alternating with finely bedded or even laminated mudstones (Ferry et al., 2007), thus producing favorable conditions for the preservation of a rich fauna (Fuchs and Weis, 2009).

In Lebanon, deposition of micritic limestones and chalks began after the Turonian and continued until the Eocene (Ferry et al., 2007). The Santonian Lagerstätte of Sahel Aalma is composed of fine-grained, chalky limestones that were probably deposited in much deeper conditions than those recognized in Hajoula or Haqel. All coleoid specimens from the Lebanese Lagerstätten are preserved as compressions on slabs. Based on the assumption that vampyropod gladii derive from a belemnoid organic proostracum, an original organic composition is supposed for Mesozoic gladii (Doguzhaeva and Mutvei, 2003). Fuchs (2006a) thus suggested that the Lebanese gladii were most likely preserved in francolite as a diagenetic byproduct.

Contrary to Roger's interpretation (1946; planche I, fig. 2), we could not find any preserved soft parts on the nautiloids described by this author. The brown fragments interpreted by Roger (1946) as nautiloid embryos are actually fish remains. This is also the case for other specimens of nautiloids and ammonites from the MNHN Dubertret collection.

\section{Systematic paleontology}

A total of 16 gladius-bearing coleoid specimens from the MNHN Dubertret, Arambourg, and En Nammoura collections have been studied, including two specimens previously illustrated by Roger (1946, MNHN.F.R06751, p. 14-16, pl. 4, fig. 5; MNHN.F.R06746, p. 14-16, pl. 9, figs. 1-2). We used UV-light to highlight soft tissues, using a UV wavelength of $365 \mathrm{~nm}$. The gladius anatomical terminology follows Fuchs and Larson (2011a, 2011b; Fig. 3). Measured characters were median field length $(m f l)$, median field width $(m f w)$, total body length, maximum body width, and arm length. These measurements are standard in most published studies on coleoids (e.g. Fuchs and Larson, 2011a, 2011b). The "arm length" corresponds to the measurement of the longest arm visible on the studied specimen. We only measured the most complete specimens (i.e., without fracturing or other disruption).

Material is housed in the Muséum National d'Histoire Naturelle, Paris (MNHN.F prefix).

Subclass Coleoidea Bather, 1888

Superorder Vampyropoda Boletzky, 1992

Suborder Prototeuthidina Naef, 1921

Diagnosis.-Slender gladius with triangular median field and ventrally closed (funnel-like) conus. Hyperbolar zones reduced or absent. Lateral field length less than the half gladius length. Median and lateral reinforcements present on the median field. Vestiges of septa and guard absent (Emended diagnosis after Fuchs et al. 2007b, p. 241; contra Jeletzky, 1966, p. 43-44).

Family Plesioteuthididae Naef, 1921

Diagnosis.-More or less slender prototeuthoids with a conus vane that is restricted to the posterior end and is bent down to form a pointed cone, grading anteriorly into the relatively broad, gradually tapering lateral plates, in which the median plate bears a simple or double median rib and narrow lateral bands clearly demarcated from the broad central part. (Naef, 1922, p. 111). The fins are very short, subterminal, resting on the conus (Fuchs and Larson, 2011a).

Included genera.-Plesioteuthis Wagner, 1859; Dorateuthis Woodward, 1883; Paraplesioteuthis, Naef, 1921; Romaniteuthis Fischer and Riou, 1982; Rhomboteuthis Fischer and Riou, 1982; Boreopeltis Engeser and Reitner, 1985; Senefelderiteuthis Engeser and Keupp, 1999; Nesisoteuthis Doguzhaeva, 2005.

Occurrence.-(?)Late Triassic (Rhaetian), Early Jurassic (Toarcian)-Late Cretaceous (Maastrichtian) of Europe, Central Russia, Lebanon, North America and Australia.

Genus Dorateuthis Woodward, 1883

Type species.-Dorateuthis syriaca Woodward, 1883 from the Cenomanian-Santonian of Lebanon.

Included species.-With certainty only Dorateuthis syriaca Woodward, 1883 from the Cenomanian-Santonian of Lebanon. Poorly preserved "Neololigosepia" stahleckeri Reitner and Engeser, 1982 and "Maioteuthis" morroensis Reitner and Engeser, 1982 both from the Barremian of the Cape Verde Islands; "Plesioteuthis" sp. Engeser and Reitner, 1985 and "Maioteuthis" damesi Engeser and Reitner, 1985 both from the Aptian of Heligoland (northern Germany); "Plesioteuthis" arcuata von der Marck, 1873 from the Campanian of northwestern Germany; "Plesioteuthis" maestrichtensis Binkhorst van den Binkhorst, 1861 from the Maastrichtian of the Netherlands, all of which display a narrow gladius with continuous lateral keels, were preliminarily assigned to this genus.

Diagnosis.-Gladius long and slender (ratio gladius width/ length $\sim 0.10$ ) without a median keel. Median field triangular 


\section{Prototeuthidina}

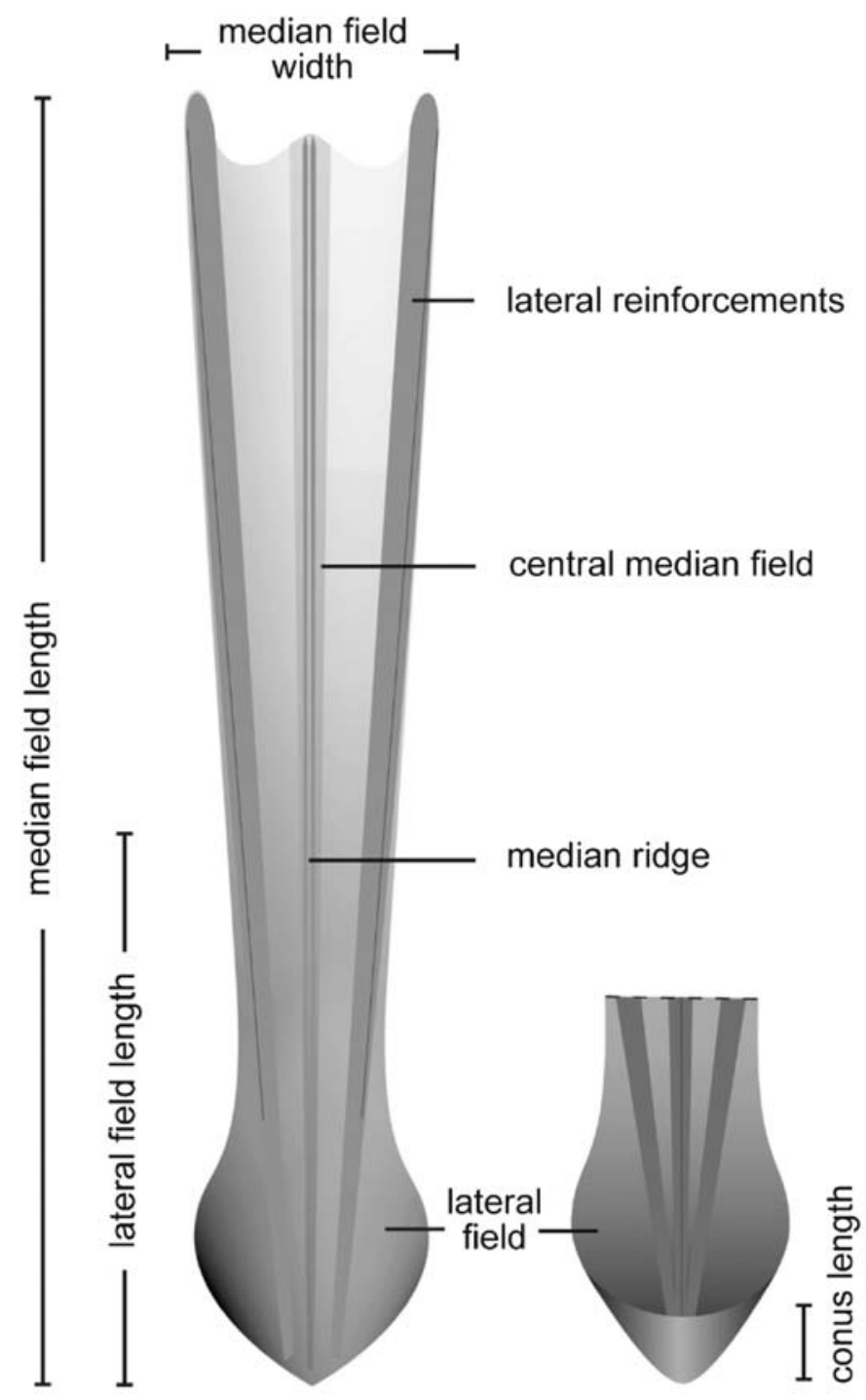

Teudopseina

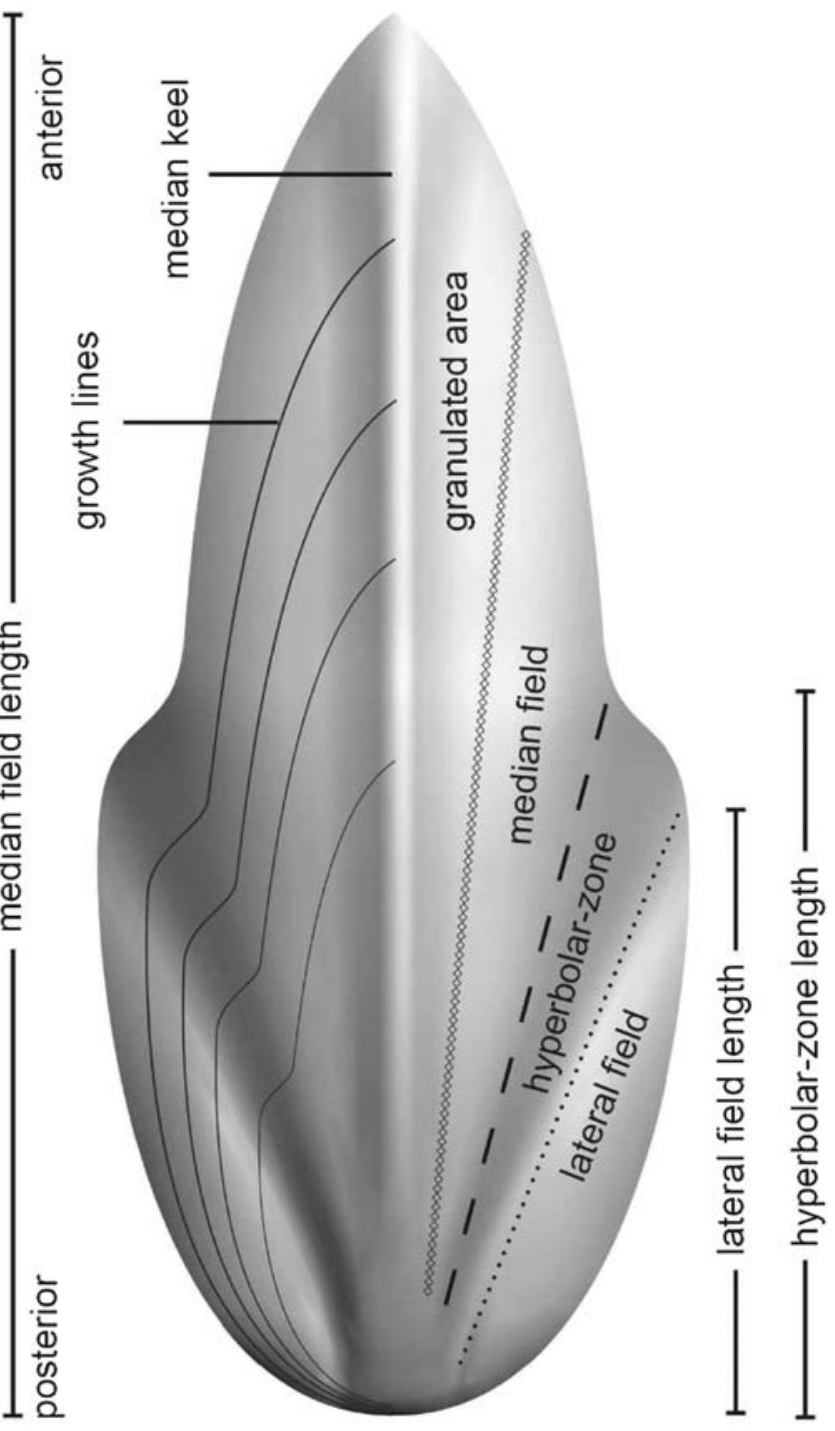

Figure 3. Terminology and measurements used for prototeuthidid and teudopseid gladii in dorsal view (Fuchs and Larson, 2011a, 2011b).

with a bipartite median ridge and pronounced lateral keels present continuously from anterior to posterior extremities. Lateral fields and conus strongly reduced (after Fuchs and Larson, 2011a).

Occurrence.-With certainty from the Cenomanian through Santonian of Lebanon (and potentially from the Barremian up to the Maastrichtian of the Cape Verde Islands, Northern Europe and Russia).

Dorateuthis syriaca Woodward, 1883

Figures 4.1-4.3, 5.1-5.5, 7.1, 9.1-9.5, 10, 11.1-11.4, $12.1-12.4,13.1-13.3,14$

1878 Sepialites Fraas, p. 346.

1883 Dorateuthis syriaca n. sp. Woodward, p. 1, pl. 1.

1888 Curculionites senonicus Kolbe, p. 135, pl. 11, fig. 8.
1896 Sepialites Woodward, p. 231.

1922 Dorateuthis syriaca; Naef, p. 118.

1922 "Plesioteuthis fraasi" Naef, p. 133, fig. 50.

1922 "Sepialites sahil-almae" O. Fraas, 1878; Naef, p. 134, fig. 49c.

1943 Sepialites sahil almae Klinghardt, p. 12, fig. 8.

1946 Leptoteuthis syriaca; Roger, pl. 4, figs. 5, 6, pl. 9, figs. 1, 2.

1952 Sepialites sahel-almae; Roger, p. 738.

1952 Leptoteuthis syriaca; Roger, p. 739.

1986 Dorateuthis sahilalmae; Engeser and Reitner, p. 3, fig. 1, pl. 1, fig. 1.

1986 ?Dorateuthis sp. Engeser and Reitner, p. 4, pl. 1, fig. 2.

1987 Sepialites sahilalmae (O. Fraas) Naef, 1922; Riegraf, p. 97.

1988 Dorateuthis sahilalmae; Engeser, p. 43.

2006a Dorateuthis cf. syriaca; Fuchs, p. 6, fig. 4, pl. 1-3.

2006b Dorateuthis sahilalmae; Fuchs, pl. 17H, pl. 22F. 

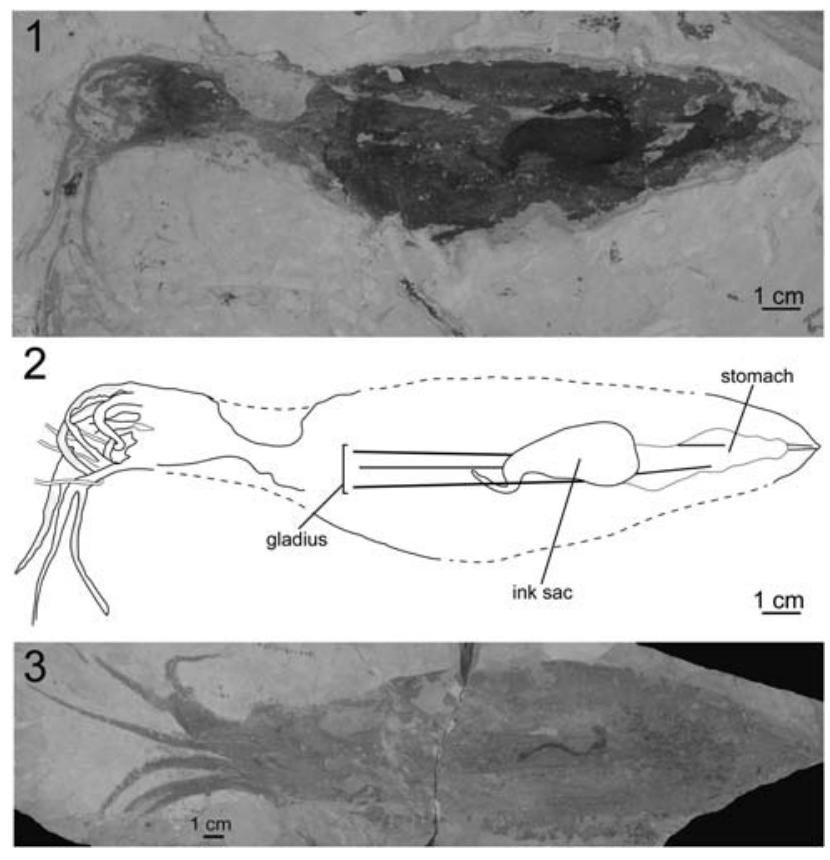

Figure 4. Dorateuthis syriaca (Woodward, 1883) specimens (1) and (2), MNHN.F.A50398; 3, MNHN.F.A50402; Santonian, Sahel Aalma, exhibiting a long and slender gladius consisting of an anteriorly diverging median field.
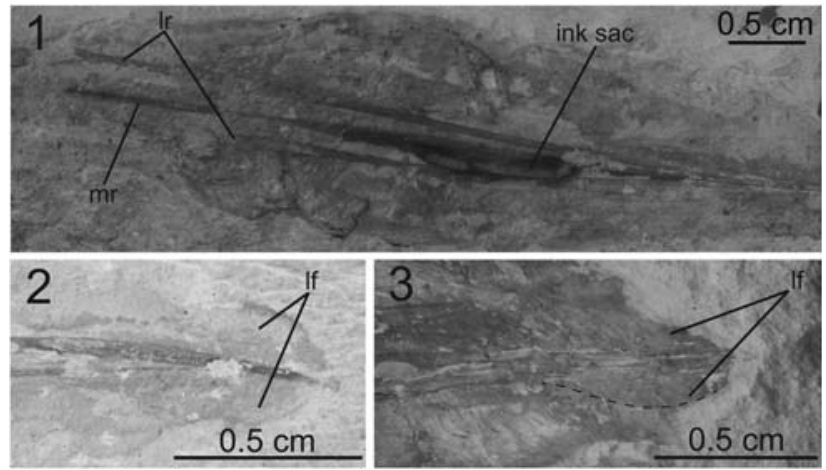

Figure 5. Gladius morphology of Dorateuthis syriaca (Woodward, 1883): (1), gladius morphology of MNHN.F.A50394; (2), lateral fields of MNHN.F. A50405; (3), lateral fields of MNHN.F.A50398. Abbreviations: $1 \mathrm{r}=$ lateral reinforcements, $\mathrm{mr}=$ median ridge, $1 \mathrm{f}=$ lateral fields.

2006b Dorateuthis syriaca; Fuchs, pl. 17I, pl. 22E.

2006b Dorateuthis sp.; Fuchs, pl. 17J.

2007b Dorateuthis syriaca; Fuchs, Klinghammer and Keupp, p. 246.

2007b Dorateuthis sahilalmae; Fuchs, Klinghammer and Keupp, p. 246.

2007 Dorateuthis syriaca; Fuchs, p. 64, fig. 4.

2007 ?Dorateuthis sahilalmae; Fuchs, p. 64.

2011a Dorateuthis syriaca; Fuchs and Larson, p. 238, figs. 2-8, fig. 7.5.

Type locality.-Sahel Aalma, Lebanon.

Occurrence.-early Late Cenomanian-Late Santonian of Lebanon; type horizon Late Santonian.

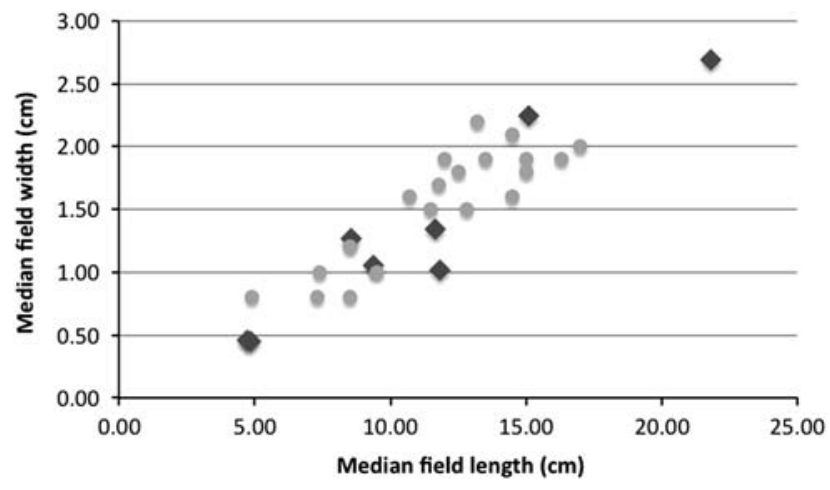

Figure 6. Scatter plot of the median field width versus median field length for 8 Dorateuthis syriaca (Woodward, 1883) studied specimens (MNHN.F.A50394, MNHN.F.A50395, MNHN.F.A50396, MNHN.F.A50398, MNHN.F.R06746, MNHN.F.A50399, MNHN.F.A50401, and MNHN.F.A50402; squares) and unpublished specimens (D. Fuchs, personal communication, 2013; circles).
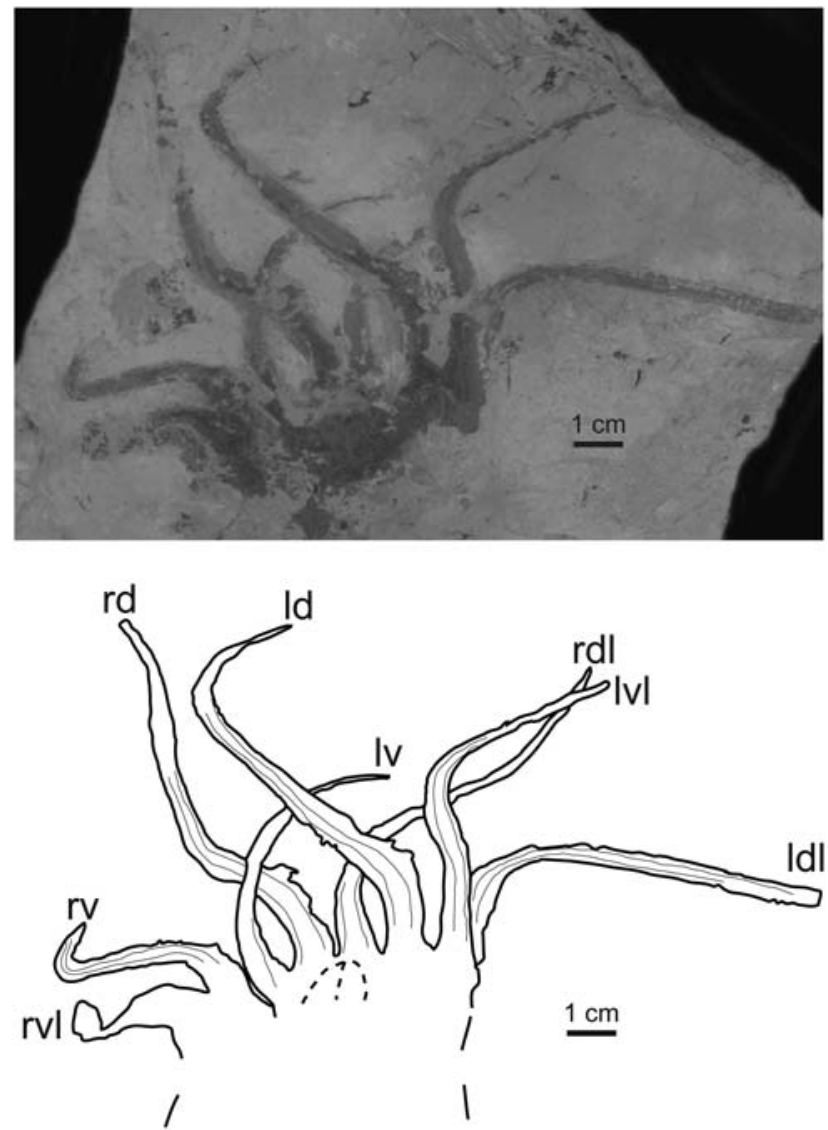

Figure 7. Arms of a Dorateuthis syriaca (Woodward, 1883) specimen, MNHN.F.A50400, Santonian, Sahel Aalma, ventral view. Abbreviations: $\mathrm{ld}=$ left dorsal, $\mathrm{rd}=$ right dorsal, $\mathrm{lv}=$ left ventral, $\mathrm{rv}=$ right ventral, $\mathrm{ld} l=$ left dorsolateral,$\quad \mathrm{rdl}=$ right dorsolateral, $\mathrm{lvl}=$ left $\quad$ ventrolateral, $\mathrm{rvl}=$ right ventrolateral.

Description.-Thirteen specimens (MNHN.F.A50394-MNHN. F.A50405, MNHN.F.R06751, and MNHN.F.R06746; all from the Santonian of Sahel Aalma) from the Dubertret collection can be assigned to $D$. syriaca based on their similar gladius morphology. They all exhibit a long and slender gladius with an anteriorly diverging median field (Fig. 4). Conspicuous lateral reinforcements extending from posterior to anterior extremities 


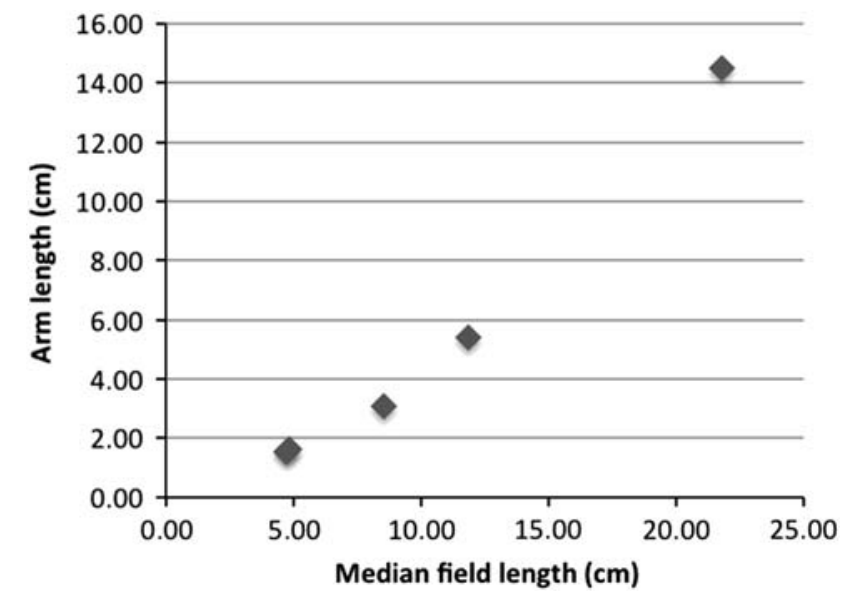

Figure 8. Arm length $/ m f l$ ratio for Dorateuthis syriaca (Woodward, 1883) specimens, MNHN.F.A50394, MNHN.F.A50395, MNHN.F.A50398, MNHN. F.R06746, and MNHN.F.A50402, Santonian, Sahel Aalma.

are visible and diverge at an acute angle of $\sim 6^{\circ}$. The thickness of the lateral reinforcements hardly increases anteriorly. This slight thickening is visible on the dorsal and ventral gladius surfaces. On most of specimens, a delicate median ridge is present and it is thinner than the lateral reinforcements. Interestingly, the specimen MNHN.F.A50394 shows a relatively strong median ridge with almost the same thickness as the lateral reinforcements (Fig. 5.1).

Three gladii show weak imprints of the lateral fields: MNHN.F.A50405 (Fig. 5.2) is a gladius of a small individual ( $\mathrm{mfl} \sim 28 \mathrm{~mm}$ ). Its lateral fields are relatively long $(6 \mathrm{~mm}$, i.e., $\sim 20 \%$ of $\mathrm{mfl}$ ) and large (3.4 mm, i.e., 12\% of $\mathrm{mfl}$ ). On MNHN. F.A50397, perceptible lateral fields are $4.5 \mathrm{~mm}$ long and $1.8 \mathrm{~mm}$ wide (the specimen is illustrated and discussed hereafter). The third gladius showing lateral fields (MNHN.F. A50398, Fig. 5.3) is of much larger dimensions ( $\mathrm{mfl} \sim 151 \mathrm{~mm}$ ). Compared to its large size, its lateral fields are relatively short and narrow $(8.1 \mathrm{~mm}$ long and $3.5 \mathrm{~mm}$ wide, i.e., $~ 5 \%$ and $2 \%$ of $m f l$, respectively). None of the 13 studied specimens yielded long and wide lateral fields as reported on the holotype by Woodward (1883). The size of the lateral fields appears partly more stable and independent relative to $m f l$ size. Thus, the lateral fields probably do not have an isometric growth relative to gladius size (i.e., the size of the lateral fields does not necessarily increase in the same proportion as the gladius). No specimen shows evidence of lateral fields with a conus.

$M f l$ and $m f w$ measurements of eight specimens (MNHN.F. A50394, MNHN.F.A50395, MNHN.F.A50396, MNHN.F. A50398, MNHN.F.R06746, MNHN.F.A50399, MNHN.F. A50401, and MNHN.F.A50402) are illustrated in Figure 6. This figure also includes unpublished measurements of Dorateuthis syriaca specimens from Haqel, Hajoula, and Sahel Aalma (Fuchs, personal communication, 2013) and these individuals all appear to be conspecific. The mean $m f w / m f l$ ratio $(\sim 0.13)$ of the MNHN specimens is also consistent with the 0.10 ratio mentioned in the emended diagnosis of the genus Dorateuthis by Fuchs and Larson (2011a). This ratio has also been estimated for the holotype of $D$. syriaca published by Woodward (1883) and it is similar ( 0.11). Overall, these observations support an assignment of MNHN.F.A50394-MNHN.F.A50405, MNHN.F.R06751, and MNHN.F.R06746 specimens to D. syriaca.

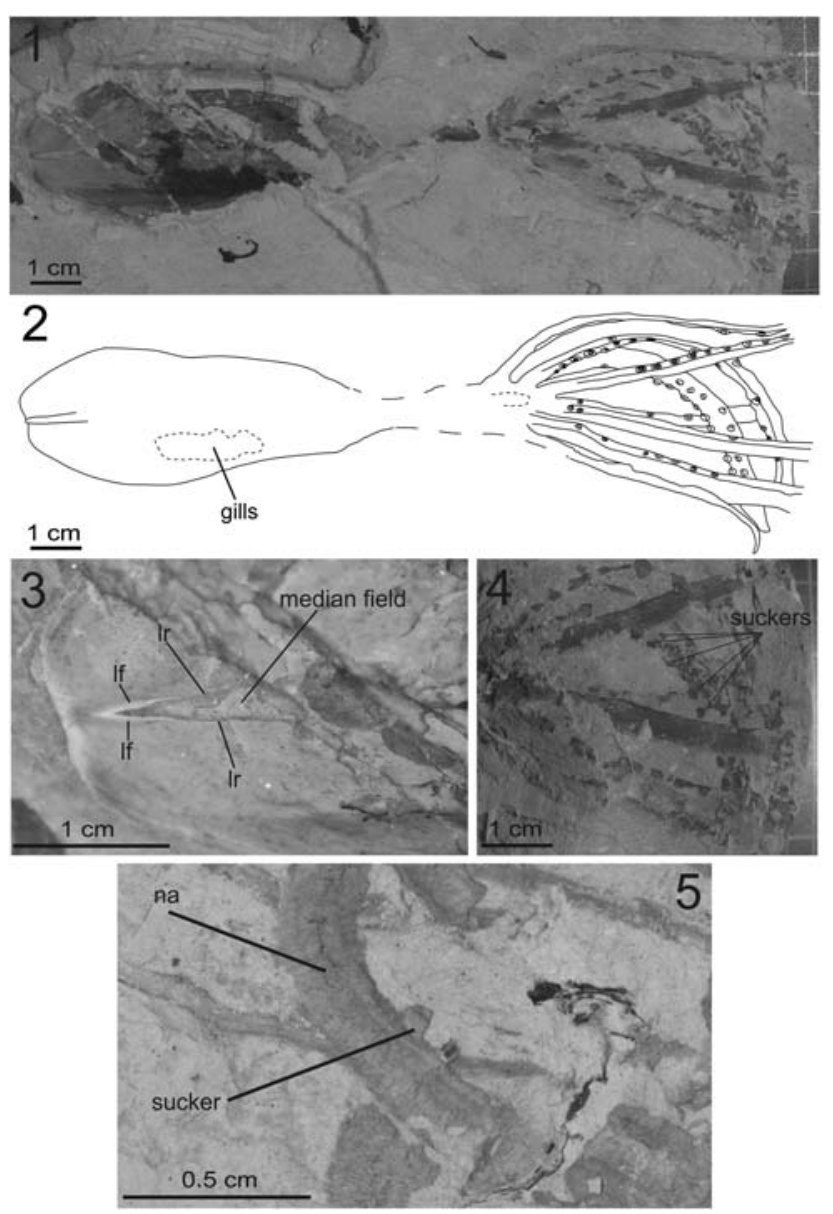

Figure 9. Sucker morphology of Dorateuthis syriaca (Woodward, 1883): (1), overall view of MNHN.F.A50397, Santonian, Sahel Aalma (dorsal view); (2), drawing of MNHN.F.A50397; (3), close-up of MNHN.F.A50397 (photographed with UV light) to show the gladius morphology; (4), close-up of the arms of MNHN.F.A50397; (5), close-up of a sucker of MNHN.F. A50398, Santonian, Sahel Aalma. Abbreviations: If $=$ lateral fields, $\mathrm{lr}=$ lateral reinforcements, $\mathrm{na}=$ nervous axis.

Five of the studied specimens (MNHN.F.A50397, MNHN. F.A50398, MNHN.F.R06746, MNHN.F.A50400, and MNHN. F.A50403) unequivocally show eight arms only. Those of specimen MNHN.F.A50400 are particularly well preserved (Fig. 7). An additional strongly elongated ventrolateral arm pair (tentacles) as drawn by Woodward (1883) for the holotype, or assumed by Naef (1922, p. 72), is not visible on any studied specimen and is therefore not supported. Difference in arm thickness is frequently observed but it most probably results from the curvature, orientation, and differential crushing of the arms. Only two specimens (MNHN.F.A50394 and MNHN.F. A50400) exhibit differences in arm thickness that apparently do not result from taphonomic processes. MNHN.F.A50400 shows exceptionally well-preserved arms whose length can be categorized into three groups (Fig. 7). MNHN.F.A50394 apparently also displays three types of arm length. This observation is in accordance with Lukeneder and Harzhauser (2004) and Fuchs and Larson (2011a) who described three coexisting types of arms with different lengths in $D$. syriaca. Fuchs and Larson (2011a) suggested that the shortest and most delicate arms are ventral and that the longest and thickest are in 


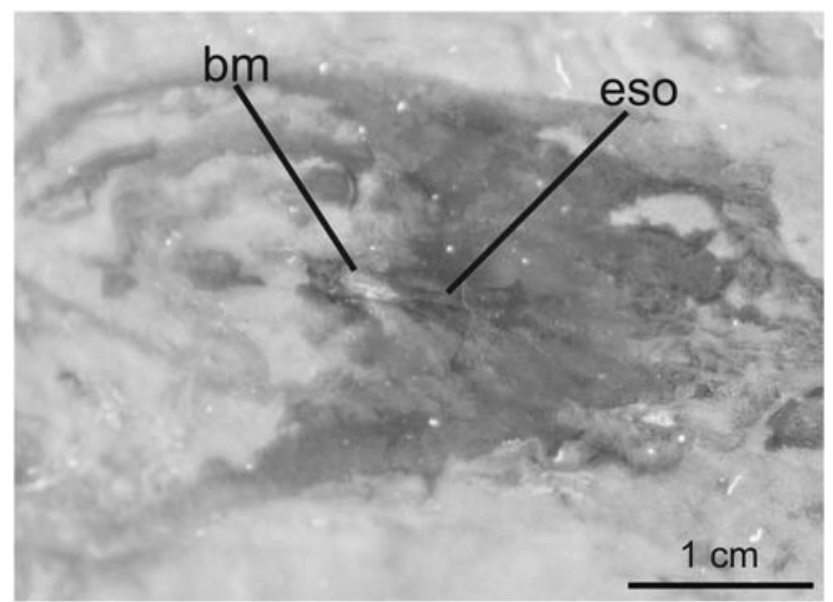

Figure 10. Buccal mass of a Dorateuthis syriaca (Woodward, 1883) specimen, MNHN.F.A50398, Santonian, Sahel Aalma (photographed under UV light). Abbreviations: $\mathrm{bm}=$ buccal mass, eso = esophagus.

dorsal position. The ventrolateral and dorsolateral arm pairs seem to be equal in length and thickness. These types of arm pairs were tentatively identified on MNHN.F.A50400 and are reported in Figure 7. A dorsal arm pair that is longer than the other arms is also a well-known feature of the Jurassic Plesioteuthis prisca (Fuchs, 2006b). On MNHN.F.A50398 (Fig. 4), four delicate "filaments" are barely perceptible but represent the distal part of highly curved arms. In most of the studied specimens, arms are narrower and more delicate on their distal part than on their proximal part.

The arm length $/ \mathrm{mfl}$ ratio is variable among five studied Dorateuthis syriaca specimens from Sahel Aalma (MNHN.F. A50394, MNHN.F.A50395, MNHN.F.A50398, MNHN.F. R06746, and MNHN.F.A50402; Fig. 8). Arms on small specimens (i.e., $m f l 5-10 \mathrm{~cm}$ ) are comparatively shorter (arm length $/ m f l$ ratio $~ 0.3-0.4)$ than those of medium-sized specimens ( $m f l \sim 12 \mathrm{~cm}$, arm length $/ m f l$ ratio $\sim 0.45$ ) and of the largest specimen ( $m f l \sim 22 \mathrm{~cm}$, arm length $/ m f l$ ratio $\sim 0.65$ ). These values are in agreement with measurements by Fuchs and Larson (2011a) who documented ratios of 0.4 for "juvenile specimens," 0.45 for "a possibly adolescent specimen" and at least 0.5 for "large specimens." We therefore agree with the hypothesis of Fuchs (2006a), who suggested that the differences in relative arm length and thickness result from allometric growth. This hypothesis is also consistent with observations made on modern cephalopods. Indeed, changes in the relative size of various body components during growth occur in most cephalopods (Boyle and Rodhouse, 2005). For instance, changes in the proportions of arms or mantle are conspicuous among squids during the paralarval and juvenile stages. Allometric differences among somatic, reproductive, and digestive components are variable and are linked to ontogeny or nutrient availability (Boyle and Rodhouse, 2005).

As for Dorateuthis syriaca individuals studied by Fuchs and Larson (2011a), none of the studied specimens yielded evidence of cirri or decabrachian characters such as hooks or horny rings. This contrasts with Woodward (1883) who mentioned the presence of hooks on the holotype. Naef $(1922$, p. 72) and Lukeneder and Harzhauser (2004, p. 4) reported faint traces of sucker-like structures on $D$. syriaca specimens from Sahel
Aalma. Fuchs and Larson (2011a) did not report suckers for $D$. syriaca specimens from Lebanon. Interestingly, one D. syriaca specimen (MNHN.F.A50397, Fig. 9.1-9.3) yielded unambiguous, exceptionally well-preserved suckers (Fig. 9.1, $9.2,9.4)$. When flattened with a lateral orientation, they show a large base, indicating that they were sessile and not pedunculate. Moreover, the suckers are organized in two rows forming transverse pairs (Fig. 9.4). Another studied specimen, but less well preserved (MNHN.F.A50398; Fig. 4), also exhibits an apparent sucker-like structure (Fig. 9.5). This is the first time that unambiguous evidence of suckers is documented for specimens of $D$. syriaca.

The preservation of the buccal mass as a white spot located anteriorly on the head is a common feature in $D$. syriaca (Fuchs and Larson, 2011a). However, only MNHN.F.A50398 yields reliable evidence of such a character (Fig. 10). On this specimen, the beaks are also discernible in the center of the buccal mass. Posteriorly to the buccal mass, a distinct cord is visible and probably represents the esophagus (Fig. 10). On MNHN.F.A50403, the esophagus appears as a cord of yellowish staining. Lukeneder and Harzhauser (2004) and Fuchs and Larson (2011a) already described these organs in prototeuthidid coleoids from Lebanon.

One studied specimen (MNHN.F.A50405) exhibits a pair of pear-shaped imprints (Fig. 11.1) located on the longitudinal axis of the body and between the anterior margin of the gladius and the supposed position of the arm base. Their outer margins are weakly curved and the inner margins appear straight and close to each other, but not connected. Fuchs and Larson (2011a) previously described such structures (Fig. 11.2) on specimens of Dorateuthis syriaca. According to these authors, these structures, when present, always appear in pairs and thus suggest a median connection. A pair of boomerang-shaped structures is also perceptible on MNHN.F.A50403. Those "boomerangs" are better seen under UV light (Fig. 11.3). Fuchs and Larson (2011a) described similar structures within the pearshaped imprints (Fig. 11.4). We never found both characters together, probably due to unsufficient preservation. However, we agree with the hypothesis of Fuchs and Larson (2011a) who suggested that the "boomerangs" and the "pears" represent the dorsal and ventral parts of the cephalic cartilage, respectively. Indeed, these structures are very similar to the ones that can be observed in modern coleoids (Nixon, 1998).

As illustrated by Fuchs and Larson (2011a) on specimens of D. syriaca from Lebanon, a structure located close to the posterior side of the cephalic cartilage of MNHN.F.A50403 is barely perceptible. It is characterized by a white rectangle in between two black rectangles (Fig. 11.3). Fuchs and Larson (2011a; Fig. 11.4) interpreted the black rectangles as statocysts, i.e., balance sensory receptor. In modern coleoids, the cephalic cartilage completely surrounds two statocysts, which are located at the same place than the observed structures (Nixon, 1998). However, the preservation is not good enough to allow a definitive anatomical assignment.

As Fuchs and Larson (2011a) did, we suggest that the cephalic cartilage of $D$. syriaca resembles the one of Vampyroteuthis Chun, 1903 in having lateral projections (Nixon, 1998, fig. 3c). Although the cephalic cartilage of MNHN.F.A50396 (Fig. 12.1) appears quite similar to that of the 

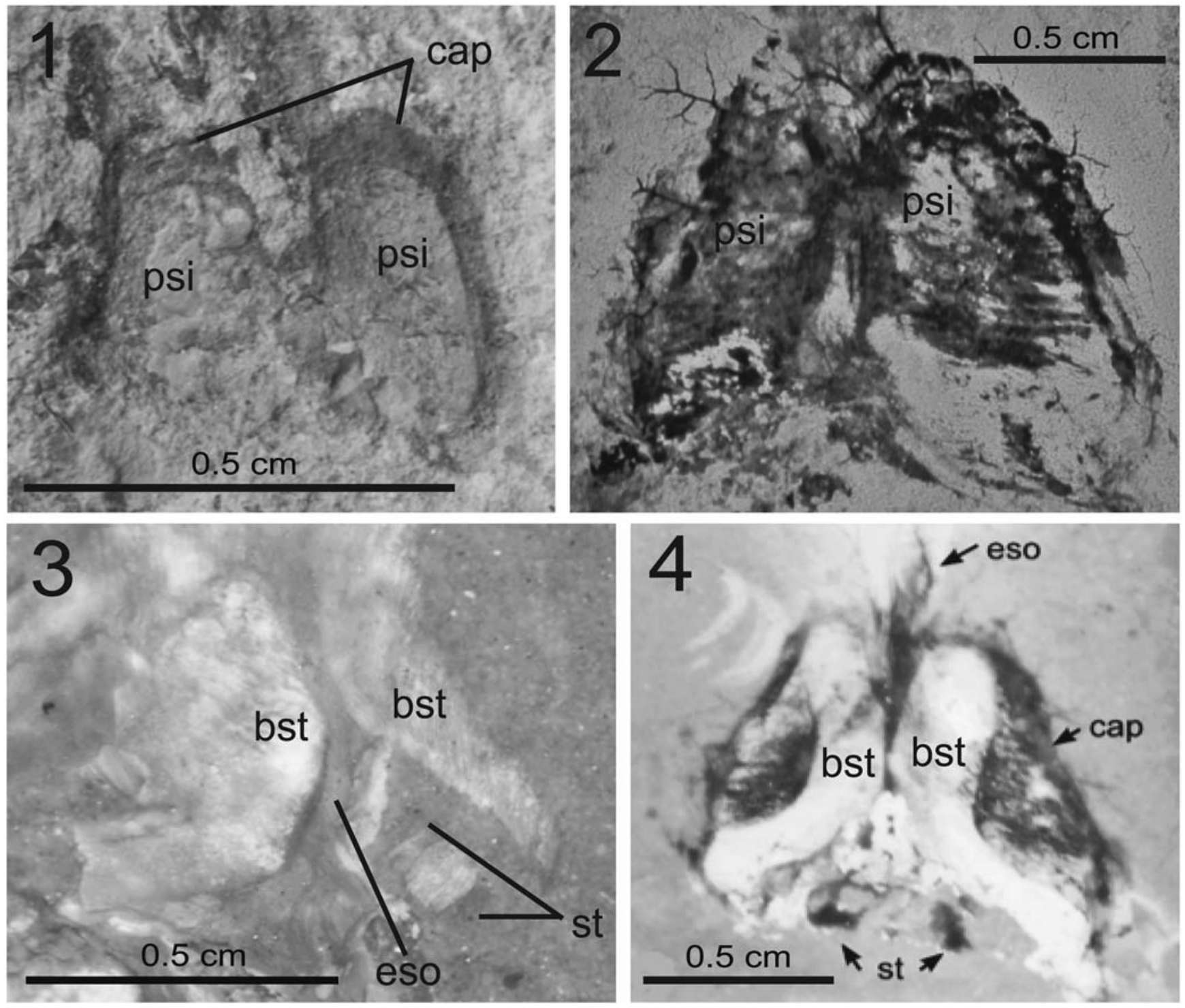

Figure 11. Cephalic cartilage morphology of Dorateuthis syriaca (Woodward, 1883): (1), MNHN.F.A50405, Santonian, Sahel Aalma; (2), MNHNL CRE047, Cenomanian, Haqel; taken from Fuchs and Larson, 2011a); (3), MNHN.F.A50403, Santonian, Sahel Aalma (photographed under UV light); (4), cephalic cartilage of a Dorateuthis syriaca specimen (taken from Fuchs and Larson, 2011a). Abbreviations: psi $=$ pear-shaped imprints, cap $=$ eye capillaries, bst $=$ boomerang-shaped structures, eso $=$ esophagus, st $=$ statocysts.

extant Gonatus fabricii Lichtenstein, 1818 (Nixon, 1998, fig. $3 \mathrm{~b})$, its structure has been disrupted by taphonomic processes. Furthermore, the phylogenetic value of this character is still poorly known, even in living taxa (Nixon, 1998).

MNHN.F.A50396 and MNHN.F.A50394 exhibit two pillshaped brown structures identified as the posterior salivary glands (Fig. 12.1 and 12.2, respectively). These two ovoid structures are symmetrical on MNHN.F.A50396 indicating that their original location along the sagittal plan is preserved on this specimen. Two faint traces of channels can also be distinguished and apparently interconnect the ovoid structures and the buccal mass (Fig. 12.1). By comparison with present-day coleoids, these pill-shaped structures are similar in form and location to the paired posterior salivary glands (Mangold and Bidder, 1989a; Mangold and Young, 1998). This is also in accordance with the interpretation of Lukeneder and Harzhauser (2004) of similar but less well-preserved structures from a Dorateuthis syriaca specimen from Sahel Aalma (Fig. 12.3). Fuchs and Larson (2011a) did not observe such structures on other D. syriaca specimens. However, these pill-shaped structures strongly ressemble those interpreted as eye capsules by Fuchs and Weis (2009, illustrated here in Fig. 12.4) and by Fuchs and Larson (2011b) for teudopseid coleoids from the Cenomanian of Haqel and Hajoula. Based on this resemblance, the identification as "eye capsules" of the pill-shaped brown structures observable in Fuchs and Weis (2009) and Fuchs and Larson (2011b) appears unlikely to us. Indeed, the pill-shaped brown structures observed in MNHN.F.A50394 and MNHN.F.A50396 rather represent posterior salivary glands, simply because $D$. syriaca is not supposed to possess eye capsules (as stated by Fuchs and Larson, 2011a, p. 241 and Fuchs and Larson, 2011b, p. 827). Consequently, the similar structures observable in Fuchs and Weis (2009) and Fuchs and Larson (2011b) should also be posterior salivary glands rather than eye capsules. 


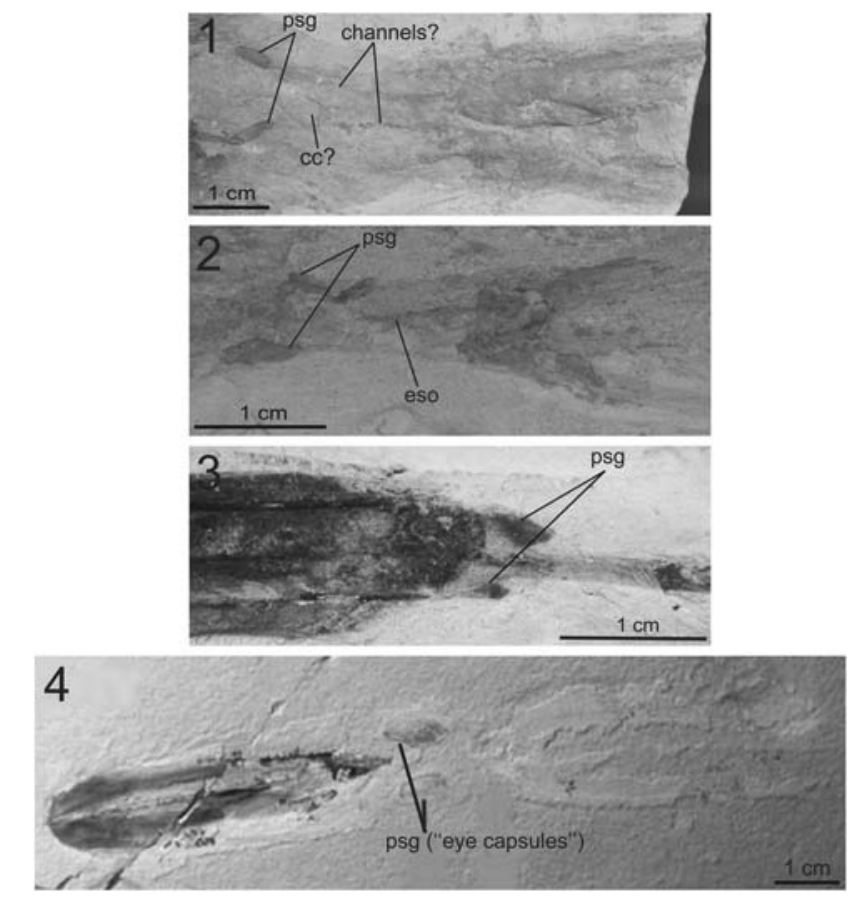

Figure 12. (1), posterior salivary glands of a Dorateuthis syriaca (Woodward, 1883) specimen, MNHN.F.A50396, Santonian, Sahel Aalma; (2), posterior salivary glands of a D. syriaca specimen, MNHN.F.A50394 (Santonian, Sahel Aalma), laterally to the esophagus; (3), posterior salivary glands of a D. syriaca specimen (NHMW1998z0105/0000, Santonian, Sahel Aalma; modified from Lukeneder and Harzhauser, 2004); (4), posterior salivary glands of Glyphiteuthis abisaadiorum (taken from Fuchs and Weis, 2009), CRE042, Cenomanian, Hajoula (modified from Fuchs and Weis, 2009). Abbreviations: $p s g=$ posterior salivary glands,$c c=$ cephalic cartilage, eso $=$ esophagus.

Furthermore, some of the pill-shaped structures (on MNHN.F.A50394 and MNHN.F.A50405, and on teudospeid specimens described in Fuchs and Weis, 2009 and Fuchs and Larson, 2011b) appear to be too distant from each other to represent eye capsules. Indeed, if the cephalic cartilage simply consists of eye capsules in teudopseid coleoids as stated by Fuchs and Larson (2011a), these eye capsules should presumably be closer to each other. Moreover, MNHN.F.A50396 exhibits a cephalic-like structure (Fig. 12.1) relatively distant from the pill-shaped structures. Both structures are anatomically dissociated. Consequently, these observations call for the identification as posterior salivary glands for these pill-shaped structures. As a whole, our anatomical re-interpretation means that a true cephalic cartilage has not been found yet in teudopseid coleoids and that it would be documented in D. syriaca only. Paired posterior salivary glands are known in modern decabrachians (Sepiida Zittel, 1895) but also in modern vampyropods (Octopoda Leach, 1818). Glands observed in D. syriaca are quite similar to those of the modern Sepia officinalis Linnaeus, 1758 as described in Mangold and Bidder (1989a) and Mangold and Young (1998). However, this organ probably carries little phylogenetic information. Incidentally, when the pill-shaped structures are located close to the buccal mass (as illustrated in Fuchs and Larson, 2011b), they may correspond to the anterior salivary glands rather than to eye capsules (Mangold and Young, 1998).

Feather-like structures occur in MNHN.F.A50397 along the lateral mantle margin and may represent gill remains (Fig. 13.1).
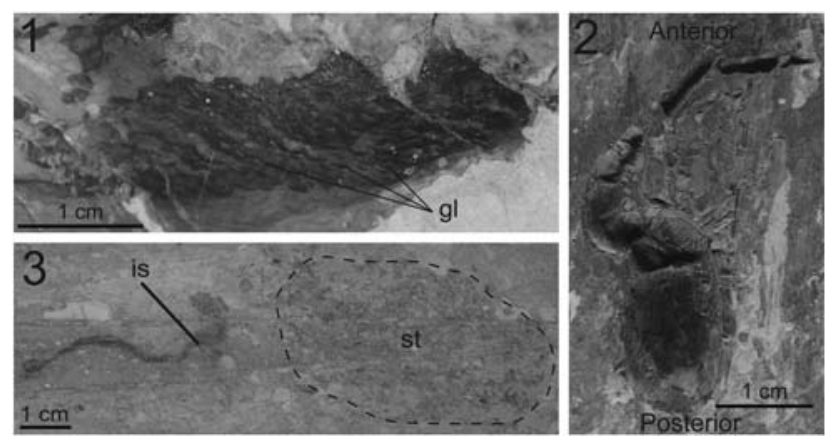

Figure 13. (1), gills of a Dorateuthis syriaca (Woodward, 1883) specimen, MNHN.F.A50397, Santonian, Sahel Aalma; (2), ink sac and stomach of MNHN.F.A50402, Santonian, Sahel Aalma; (3), ink sac of MNHN.F.A50401, Santonian, Sahel Aalma. Abbreviations: $\mathrm{gl}=$ gills lappets, is $=$ ink sac, st $=$ stomach

They markedly differ from the surrounding matrix by their darkened colour. A series of at least 16 long lappets branching off from a longitudinal axis is visible. This latter is similar to the branchial membrane in modern coleoids (Mangold and Bidder, 1989b). Our observation reinforces the hypothesis of Fuchs and Larson (2011a, p. 239) who stated that "these structures might represent remains of the cartilaginous gill skeleton [...] but it clearly reflects the primary efferent gill vessel and its outer branches (= secondary efferent vessels, branchial laminae)". The gills of D. syriaca resemble those of Plesioteuthis prisca (Bandel and Leich, 1986; Haas, 2002) in that they have a large number of branchial laminae. The incirrate octopods Keuppia levante and Keuppia hyperbolaris Fuchs et al., 2009 from Hajoula apparently show only six or seven branchial laminae (Fuchs et al., 2009). Branchial laminae have also been reported from the belemnoid "Phragmoteuthis" conocauda Quenstedt, 1849, but their total number remains unclear (Reitner, 2009). Gill morphology of Dorateuthis syriaca, as well as of Plesioteuthis prisca, ressembles that of modern teuthids in having numerous gill blades (Reitner, 2009). However, this can be seen as a homoplasy. Indeed, according to Reitner (2009), gill type is most probably due to lifestyle and has no phylogenetic significance.

Almost all specimens described here exhibit a relatively large 3-D black structure located at mid-length of the mantle (Fig. 13.2). Similar structures have been interpreted as the ink sac (Fuchs, 2006a; Fuchs and Larson, 2011a, 2011b) and we agree with this interpretation. According to Fuchs (2006a), the preservation of an ink sac is common in the Cretaceous coleoids from the Lebanese Lagerstätten, but its presence is phylogenetically uninformative. It also appears that in fossil coleoids, the stomach is frequently characterized by fish remains (Fig.13.3). Nearly all coleoids have an ink sac, except some deepwater species and the night-active shallow-water octopus Ameloctopus Norman, 1992, presumably because ink ejection has been counter-selected in dark environments (Boyle and Rodhouse, 2005). The observed glands (Fig. 14) appear to be quite similar to the one seen in Loligo Lamarck, 1798 and even more in Sepia Linnaeus, 1758 where the reservoir spreads on the back and reaches the bottom of the sac (Mangold et al., 1989b). On the contrary, in Octopus Cuvier, 1797, the glands fully occupy the bottom of the sac (Mangold et al., 1989b). Remarkably, the 


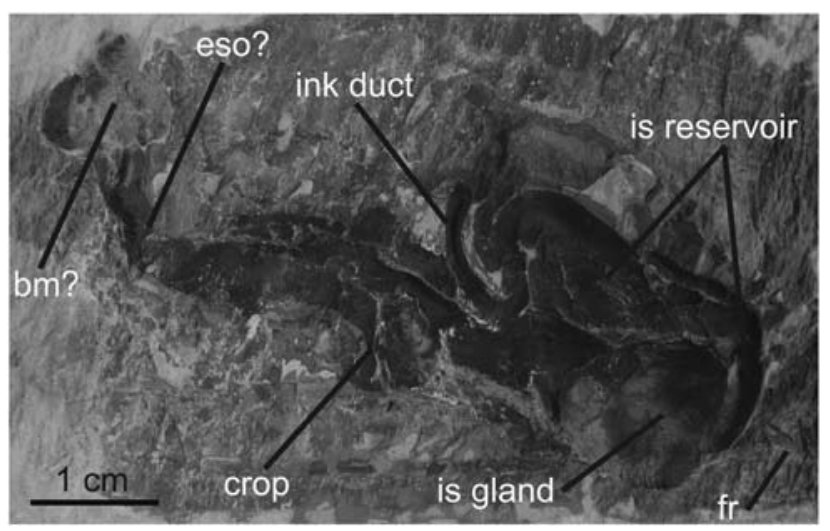

Figure 14. Digestive system of a Dorateuthis syriaca (Woodward, 1883) specimen, MNHN.F.R06746, Santonian, Sahel Aalma. Abbreviations: $\mathrm{bm}=$ buccal mass, eso $=$ esophagus, is reservoir $=$ ink sac reservoir, is gland $=$ ink sac gland, $\mathrm{fr}=$ fish remains $($ stomach).

presence of a crop is suggested in MNHN.F.R06746 by a distinct bulge within the black structure (Fig. 14). Contrary to the potential crop described by Lukeneder and Harzhauser (2004) and Fuchs and Larson (2011a), we report here an anteriorly-located crop that is distant from the stomach, as observed in modern Octopus (Mangold and Bidder, 1989a and Mangold and Young, 1998). Specimen MNHN.F.R06746 also exhibits a peculiar ventral trilobated structure at the anterior part of the black structure (Fig.14). Roger (1946) interpreted this feature as a rectal bulb and this assumption cannot be discarded. However, an alternative interpretation could be the remains of a buccal mass. Indeed, this trilobate morphology is quite similar to the buccal mass in extant coleoids (Mangold and Bidder, 1989a; Mangold and Young, 1998).

Up to now, a well-preserved continuous digestive tract consisting of a buccal mass, an esophagus, a crop and a stomach, has only been described for specimens of $D$. syriaca (Lukeneder and Harzhauser, 2004; Fuchs and Larson, 2011a), and this digestive tract thus cannot be compared with other known fossil cephalopods.

Remarks.-Dorateuthis syriaca is the most abundant coleoid in the Haqel and Hajoula localities (Fuchs and Larson, 2011a). Roger (1946, p.14) stated that D. syriaca was also relatively frequent in Sahel Aalma, making this taxon the most abundant Cretaceous coleoid in Lebanon. In his original description, Woodward $(1883$, p.3) stated that the gladius of $D$. syriaca is marked by "three equidistant ridges, one median and two lateral, which converge together at the very acute distal extremity," and also by "two extremely delicate lateral expansions." Naef (1922, p. 72) presumed a strong median rib and doubted the presence of lateral fields. However, Roger (1946, p. 14) reported long and wide lateral fields and therefore regarded the gladius as close to the Jurassic Leptoteuthis (suborder Teudopseina). Recently, Fuchs (2006a, p. 7) redescribed D. syriaca from the Cenomanian of Haqel and Hadjoula and concluded that if lateral fields are present, they must be extremely short and narrow. Interestingly, the gladius of $D$. syriaca is similar in shape to the gladius of the Early Jurassic Paraplesioteuthis sagittata Münster, 1843; the Middle Jurassic Romaniteuthis gevreyi
Roman, 1928; and the Late Jurassic Senefelderiteuthis tricarinata, Münster, 1846. They all show a slender gladius that is flanked by lateral reinforcements. According to Fuchs and Larson (2011a), D. syriaca mainly differs from these Jurassic taxa by the absence of well-defined lateral fields. However, three studied specimens (MNHN.F.A50397, MNHN.F.A50398, and MNHN.F.A50405; Figs. 5.2 and 5.3) exhibit well-defined lateral fields, suggesting that these characters were partly missing on the specimens described by Fuchs and Larson (2011a). These authors (p. 237, fig. 2.7) described a small D. syriaca specimen from Sahel Aalma with lateral fields equivalent to $\sim 10 \%$ of the $m f$ and $6 \%$ of the $m f w$. Therefore, it appears that the "absence of true lateral fields" as stated by Fuchs and Larson (2011a) cannot be used to distinguish D. syriaca from Paraplesioteuthis sagittata, Romaniteuthis gevreyi, and Senefelderiteuthis tricarinata. Instead, we suggest that $D$. syriaca differs from $P$. sagittata and $R$. gevreyi in having smaller lateral fields.

Fuchs et al. (2007b) considered the genus Senefelderiteuthis as a junior synonym of the genus Dorateuthis, but recently Fuchs and Larson (2011a) re-established Senefelderiteuthis and assigned "Dorateuthis" tricarinata to this genus, based on the presence of well-defined lateral fields. However, MNHN specimens of $D$. syriaca exhibiting well-defined lateral fields show that the differences between D. syriaca and Senefelderiteuthis tricarinata are tenuous for this feature. According to Fuchs and Larson (2011a), D. syriaca also differs from $S$. tricarinata by the presence of a median ridge. However, it could be argued that the lack of a delicate median ridge in $S$. tricarinata is possibly a preservation artefact. In agreement with Fuchs et al. (2007b), we find difficult to distinguish $S$. tricarinata and $D$. syriaca based on gladius features. However, S. tricarinata apparently shows longer arms than D. syriaca (Fuchs and Larson, 2011a).

The gladius of $D$. syriaca is also similar to the gladius of the Jurassic coleoids Plesioteuthis subovata Münster, 1846 and Plesioteuthis prisca Rüppell, 1829. According to Fuchs and Larson (2011a), these two taxa can be distinguished from $D$. syriaca by the presence of a distinct median ridge and the absence of continuous lateral reinforcements. For Fuchs et al. (2007b), these two qualitative characters clearly separate Dorateuthis from Plesioteuthis and other plesioteuthidid genera. However, the sketch of the gladius of P. prisca in Fuchs and Larson (2011a, fig. 7.4, p. 243) shows the presence of continuous lateral keels. This illustration has thus to be corrected.

Furthermore, we observed in MNHN.F.A50394 a strong median ridge presenting almost the same thickness as the lateral reinforcements (Fig. 5.1). This contrasts with Fuchs and Larson (2011a), who considered D. syriaca as being characterized by a weak median ridge. Such a strong median ridge is in better agreement with the description of $D$. syriaca by Naef (1922, p. 72). Based on this new observation, we suggest that a "pronounced median keel" (Fuchs and Larson, 2011a) is not a truly reliable character to distinguish $P$. prisca and $P$. subovata from $D$. syriaca. In addition, biometric values are similar for both $P$. prisca and D. syriaca (Fig. 6; Fuchs et al., 2007b, p. 244, fig. 2). Based on soft-part morphology, P. prisca can be distinguished from D. syriaca by shorter arms (Fuchs and Larson, 2011a).

We conclude that diagnostic characters that unambiguously identify D. syriaca are rare. According to Fuchs and Larson (2011a), 
D. syriaca was characterized by the presence of a delicate median ridge and the absence of true lateral fields. However, two of the specimens studied here show the opposite features and suggest that the gladius characters used to diagnose D. syriaca are highly variable among specimens according to their preservation. Even though $P$. subovata may be distinguished from D. syriaca by larger lateral fields (Fuchs et al., 2007b, fig. 3C), the gladius differences between $D$. syriaca and $P$. prisca are much more tenuous.

Order Octobrachia Fioroni, 1981

Suborder Teudopseina Starobogatov, 1983

Diagnosis._-Gladius with clearly reduced, opened, and spoonshaped conus. Lateral fields and hyperbolar zones $55 \%$ and less of the median field length. Hyperbolar zones located between lateral and median field as well-developed broad furrows. Anterior median field more or less pointed (after Fuchs and Weis, 2009).

Families included.-Trachyteuthididae, Naef, 1921; Palaeololiginidae, Naef, 1921; Teudopsidae, Regteren Altena, 1949; Muensterellidae, Roger, 1952.

Family Trachyteuthididae Naef, 1921

Diagnosis.-Teudopseid vampyropods with granules (tubercles) on the dorsal surface of the gladius.

Included genera.-Glyphiteuthis Reuss, 1854; Actinosepia Whiteaves, 1897; Glyphidopsis Fuchs and Larson, $2011 \mathrm{~b}$.

Occurrence.-Middle Jurassic (Callovian)-Late Cretaceous (Maastrichtian) of Europe, Central Russia, Lebanon, Cuba, Chile, Antarctica, Australia, North America, and Mexico.

\section{Genus Glyphiteuthis Reuss, 1854}

Other species.-Glyphiteuthis boutillieri (Lennier, 1866); Glyphiteuthis libanotica (Fraas, 1878); Glyphiteuthis abisaadiorum Fuchs and Weis, 2009; Glyphiteuthis rhinophora Fuchs et al., 2010a; Glyphiteuthis freijii Fuchs and Larson, 2011b.

Diagnosis.-Trachyteuthidid gladius with hyperbolar zone length $/ m f$ ratio of $0.33-0.39$. Anterior median field sharply pointed and with a mid-dorsal keel-like elevation. Angle of diverging inner asymptotes $20^{\circ}-40^{\circ}$. Head not fused with the dorsal mantle. Cephalic cartilage ring-shaped. Two pairs of lobate fins.

Occurrence.-Late Cenomanian of Lebanon and France, early/ middle Turonian of Czech Republic and Mexico, Late Santonian of Lebanon.

\section{Glyphiteuthis libanotica (Fraas, 1878)}

Figure 15

1878 Geoteuthis libanotica Fraas, p. 345, pl. 6, fig. 3.

1922 Trachyteuthis libanotica; Naef, p. 140, fig. 49b.
1942 Libanoteuthis libanotica; Kretzoi, p. 125, fig. 1.12, p. 134.

1946 Trachyteuthis libanotica; Roger, p. 17, fig. 10.

1952 Libanoteuthis libanotica; Roger, p. 740.

1962 Libanoteuthis libanotica; Rioult, p. 11, fig. $1 \mathrm{~b}$.

1966 Trachyteuthis (Libanoteuthis) libanotica; Jeletzky, p. 45.

1977 Trachyteuthis libanotica; Donovan, p. 32.

1977 Palaeololigo libanotica; Donovan, p. 37.

1986 Libanoteuthis libanotica; Engeser and Reitner, p. 7, fig. 2, pl. 2, fig. 1, 2.

1988 Libanoteuthis libanotica; Engeser, p. 69.

2006a Glyphiteuthis libanotica; Fuchs, p. 12, fig. 8, pl. 8, Fig. A-B, pl. 9 A-C.

2006b Libanoteuthis (Trachyteuthis) libanotica; Fuchs pl. 15D-E.

2007 Glyphiteuthis libanotica; Fuchs p. 64, fig. 3.

2009 Glyphiteuthis libanotica; Fuchs and Weis, p. 176, fig. 3C, fig. A-D.

2010a Glyphiteuthis libanotica; Fuchs et al., fig. 4A, E, fig. 5B.

2010 Glyphiteuthis libanotica; Larson et al., fig. 3B, fig. 4A-C.

2011b Glyphiteuthis libanotica; Fuchs and Larson, p. 818, fig. 3.2, figs. 4-7.

Occurrence.-Early late Cenomanian of Haqel and Hajoula (Lebanon), (?)Santonian of Sahel Aalma (Lebanon).

Description.-The studied gladius (MNHN.F.A50406; from the Cenomanian of Haqel) is unique and relatively damaged (Fig. 15), but a morphological description and a taxonomic identification are possible. This specimen is $103 \mathrm{~mm}$ in $\mathrm{mfl}$ and is seen in ventral view. The anterior median field is sharp. Halfway along the gladius, the $m f w$ is $21 \mathrm{~mm}(\sim 20 \%$ of the $m f l)$. The width continuously decreases anteriorly, but at $\sim 70 \%$ of the $m f l$ from its posterior extremity, the median field is weakly constricted. Based on distinct growth increments, the gladius can be subdivided into a median field, a pair of comparatively wide and long hyperbolar zones, and a pair of lateral fields. Hyperbolar zone length represents $\sim 37 \%$ of the $\mathrm{mfl}$. Outer asymptotes are distinct, but inner asymptotes are barely perceptible. The outer asymptotes diverge at an angle of $25^{\circ}$. Inner asymptotes appear to diverge at an angle of $\sim 15^{\circ}$. Laterally, outspread lateral fields form a rounded posterior gladius end. A granulation is visible as a negative relief on the median field. Halfway along the gladius, the granulated area is relatively wide and diverges at an angle of $10^{\circ}$. The granulated area also does not seem to reach the anterior, posterior, and lateral margins of the gladius. The granulation is very thin on the posterior part of the gladius and it becomes more conspicuous toward the anterior part. Imprints of the growth increments are well preserved on the posterior part of the gladius. The posterior end shows an M-like shape. Within the same posterior area, two symmetrical half-ovoid structures are visible and may represent imprints of fin cartilages (i.e., fin attachments). There is no evidence of soft parts attached to the gladius.

Remarks.-Potential affinities with the suborders Loligosepiina and Prototeuthidina can be excluded as these two suborders are characterized by a gladius with a triangular anteriorly diverging 

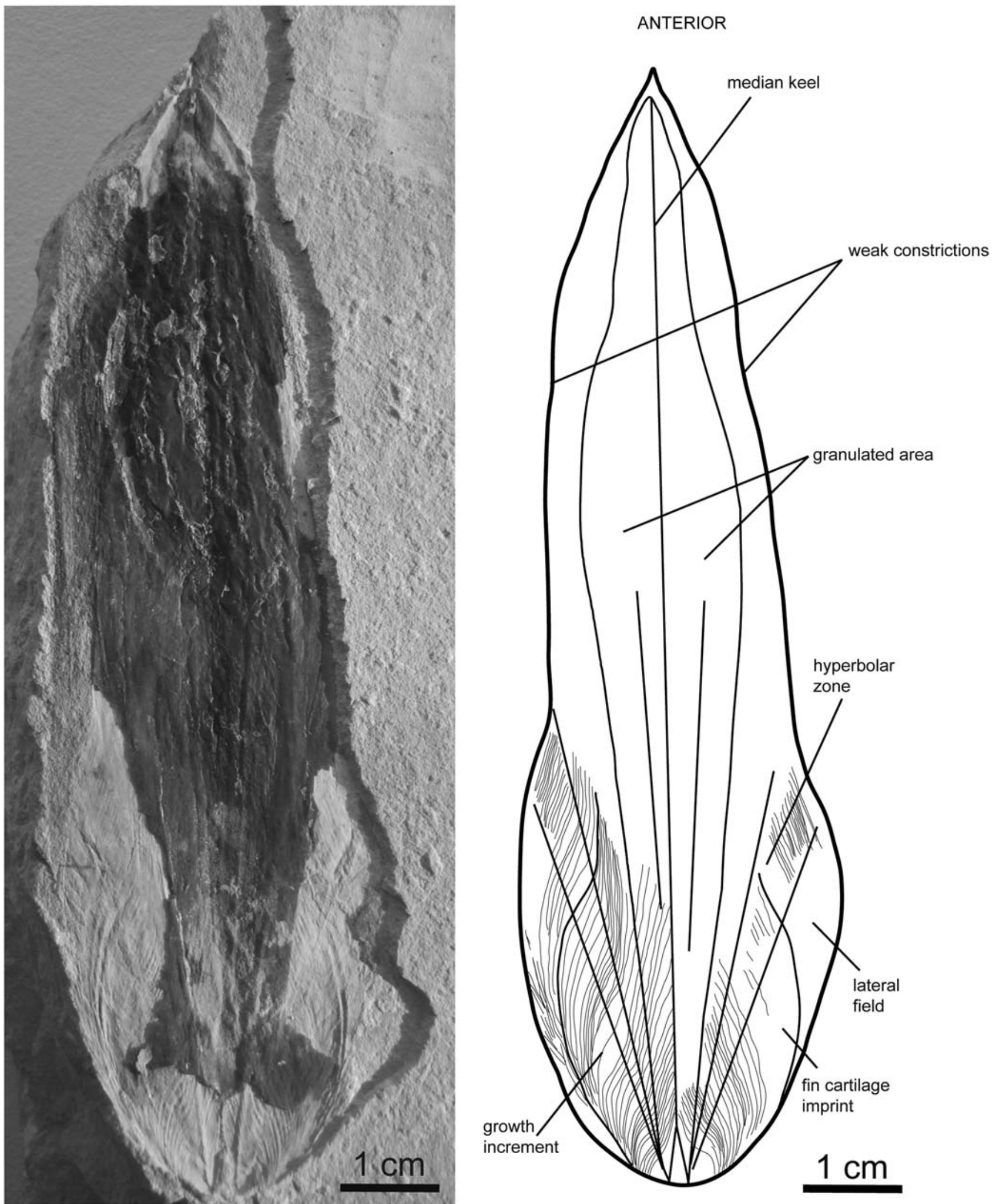

Figure 15. Gladius morphology of Glyphiteuthis libanotica (Fraas, 1878), MNHN.F.A50406, Cenomanian, Haqel, ventral view. All growth increments have not been drawn.

median field and the absence of a prominent median keel (Fuchs and Larson, 2011b). Compared to the Jurassic Trachyteuthis and Actinosepia, the specimen described here is more slender and anteriorly sharper. The Cretaceous genus Glyphidopsis strongly differs from the studied specimen in having a hyperbolar zone length representing more than $50 \%$ of the $\mathrm{mfl}$. The studied 
specimen very likely pertains to the genus Glyphiteuthis because of the granulation of the dorsal surface and of the hyperbolar zone length $/ \mathrm{m} f \mathrm{ratio}(\sim 0.37)$ that is similar to that of Glyphiteuthis libanotica (0.39) documented by Fuchs and Weis (2009). Placement of Glyphiteuthis within the family Trachyteuthididae is commonly accepted owing to the presence of granules on the dorsal gladius surface.

The specimen described here is very likely conspecific with Glyphiteuthis libanotica. This species differs from Glyphiteuthis ornata by its dorsal granulation that is significantly wider. Additionally, G. ornata exhibits a row of very coarse granules on the top of the median keel, whereas G. libanotica show a homogeneous granulation (Fuchs and Larson, 2011b). The homogeneous and large granulated surface of the studied specimen justifies its attribution to G. libanotica. G. libanotica and Glyphiteuthis freijii can be distinguished by a marked constriction close to the end of the anterior median field in G. freijii. Glyphiteuthis abisaadiorum is generally distinguished from G. libanotica by its narrower gladius morphology with a $m f w / m f l$ ratio $\sim 0.16$ at half way along the gladius (Fuchs and Weis, 2009). This ratio is $\sim 0.20$ for the studied specimen and is identical to the ratio obtained by Fuchs and Larson (2011b) for G. libanotica. In addition, G. abisaadiorum does not exhibit any constriction of the anterior median field.

Glyphiteuthis libanotica was reported from the early late Cenomanian of Haqel. Roger (1946, p. 17, fig. 10) also studied two fragmentary gladii from Sahel Aalma that probably belong to G. libanotica, but their current repository is unknown and thus preventing confirmation of the potential temporal range extension of this taxon up to the Santonian. Detailed information on the presumed existence of this species in the Santonian of Sahel Aalma is given in Fuchs and Larson (2011b).

\section{Glyphiteuthis sp.}

Figure 16

Description.-The specimen (MNHN.F.A50407; from the Cenomanian of En Nammoura), seen in ventral view, exhibits a $m f l$ of $221 \mathrm{~mm}$, but it is only partly preserved. The anterior tip of the median field is angular. The posterior conus area is apparently missing. The lateral fields and hyperbolar zones are not preserved. The maximum $m f w(\sim 33 \mathrm{~mm})$ is located close to the presumed anterior end of the hyperbolar zones and it decreases continuously anteriorly. Halfway along the gladius, the $m f w$ is $\sim 14 \%$ of the incomplete $m f l$ and thus was originally smaller. The gladius is distinctly multilayered and exhibits circular depressions close to the median axis. These depressions likely correspond to the negative relief of the granules on the dorsal surface. The granulated area does not reach the lateral gladius margin and terminates at about twothirds of the $m f$. There is no evidence of constriction of the anterior median field and median keel. The lateral margins appear to be curved.

Remarks.-Similarly to Glyphiteuthis libanotica, an affinity with the suborders Loligosepiina and Prototeuthidina can be excluded. Compared to the genera Trachyteuthis and Actinosepia, the gladius of the studied specimen is more slender and anteriorly sharper. Glyphidopsis strongly differs from the specimen described here in having a relatively larger gladius. Due to the granulation of its dorsal surface, the studied specimen very likely pertains to the genus Glyphiteuthis.

Although $\mathrm{mfw} / \mathrm{mfl}$ ratios have to be interpreted with caution, the studied specimen differs from G. libanotica and G. ornata by its overall narrower gladius morphology. Indeed, the original $m f w / m f l$ ratio halfway along the gladius was $<0.14$, whereas the same ratio is $\sim 0.20$ for G. libanotica and G. ornata (Fuchs and Weis, 2009). The constriction of the anterior median field observed in G. libanotica, G. ornata, and G. freijii is absent in the specimen described here. The studied gladius resembles G. abisaadiorum in having a slender median field $(\mathrm{mfw} / \mathrm{mfl}$ ratio halfway along the gladius $\sim 0.16$ for $G$. abisaadiorum; Fuchs and Weis, 2009). It also exhibits curved lateral margins and numerous laminated layers as observed in G. rhinophora (Fuchs et al., 2010a). However, G. rhinophora mainly differs from the studied specimen by its nose-shaped anterior part of the gladius and a prominent median keel (Fuchs et al., 2010a). G. abisaadiorum differs from the studied specimen in having straighter lateral margins (Fuchs and Larson, 2011b) and an inconspicuous but distinct mid-dorsal keel (Fuchs and Weis, 2009). The specimen described here displays an additional interesting feature: the granulated area seems to occupy only the posterior two-thirds of the visible $m f l$ (Fig. 16). On the contrary, the granulated area in other Glyphiteuthis species always extends much more anteriorly.

Specimen MNHN.F.A50407 is incompletely preserved but its combination of characters is apparently unique within the genus Glyphiteuthis. Glyphiteuthis sp. share more similarities with G. rhinophora and G. abisaadiorum than with any other Glyphiteuthis species. In any case, it differs from G. libanotica. This specimen being unique, we prefer not to assign it to a particular species for the time being.

$$
\text { Family Palaeololiginidae Naef, } 1921
$$

Diagnosis.-Teudopseid gladius rachis-like anteriorly, leaf-like posteriorly. Median field narrow with a pronounced median keel. Hyperbolar zones weakly curved. Ratio hyperbolar zone length/mfl 0.23-0.42 (after Fuchs and Larson, 2011b).

Other genera.-Rachiteuthis Fuchs, 2006a; Marekites Kostak, 2002; (?) Styloteuthis Fritsch, 1910.

Occurrence.-Late Jurassic (Tithonian) of SW Germany-Late Cretaceous (Cenomanian) of Lebanon.

Genus Rachiteuthis Fuchs, 2006a

Type species.—Rachiteuthis donovani Fuchs, 2006a.

Diagnosis after Fuchs (2006a)._Palaeololiginid with a spear or shaft-like gladius; lateral fields short and spread out with a weak hyperbolar zone; conus reduced; free rachis elongated; distinct lateral ridges and a median unornamented keel extends from the posterior to the anterior extremity; body torpedo-shaped; insertions of triangular fins relatively broad; slender arms.

Occurrence.-Early late Cenomanian. 

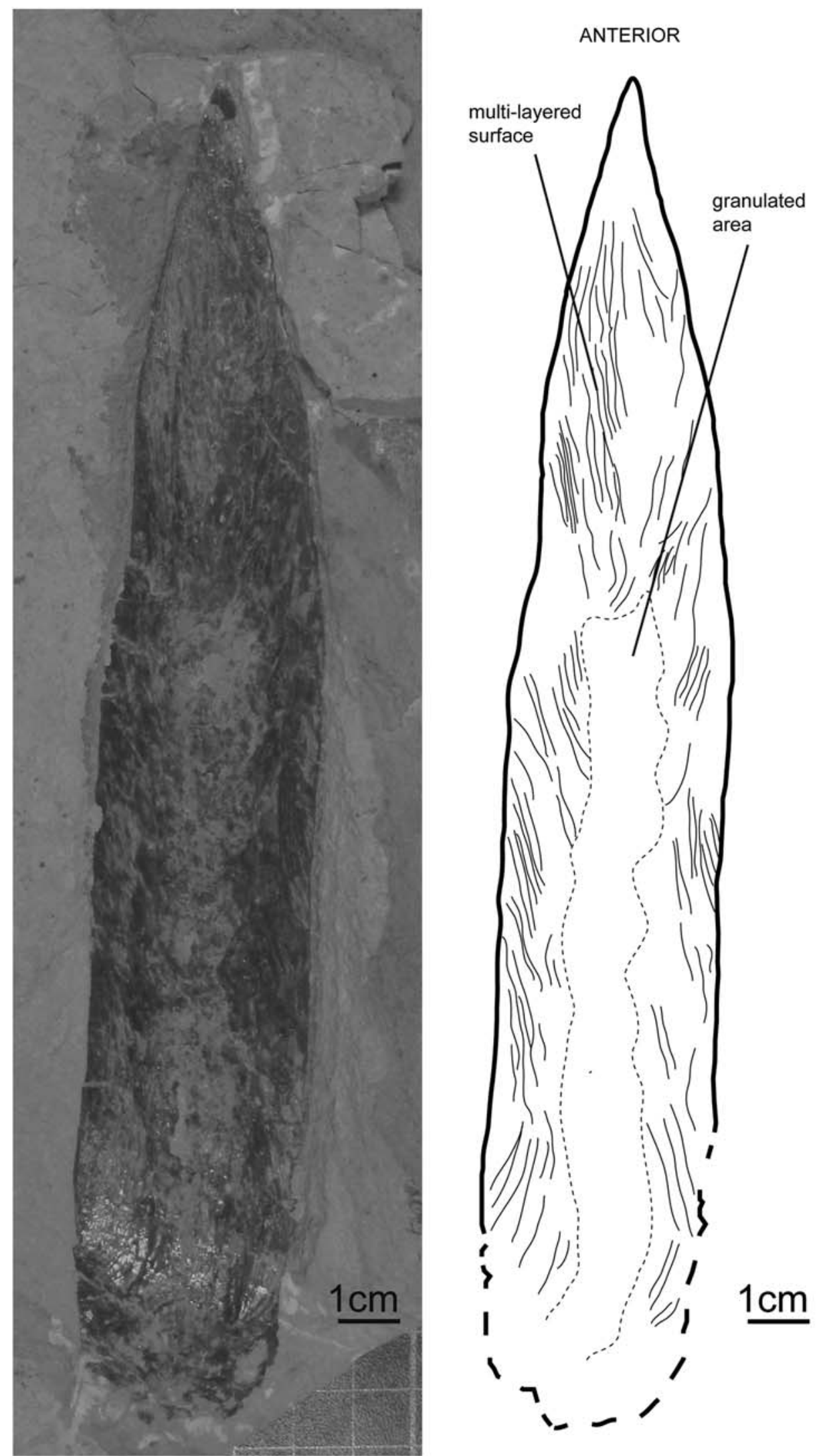

Figure 16. Gladius morphology of Glyphiteuthis sp., MNHN.F.A50407, Cenomanian, En Nammoura, ventral view. 


\section{Rachiteuthis acutali new species} Figure 17

Diagnosis.-Palaeololiginid with a spear-like gladius. Hyperbolar zones between the median field and the lateral fields poorly developed. Prominent mid-dorsal keel and lateral reinforcements. Slender and narrow anterior tip, appearing to be the prolongation of the mid-dorsal keel. Without the tip, hyperbolar zone length $/ m f$ ratio $\sim 0.3$.

Description.-The holotype (MNHN.F.A50408; from the Cenomanian of Hajoula), seen in dorsal view, shows a wellpreserved slender gladius consisting of a rachis-like median field and well-developed lateral fields. A median unornamented keel extends from posterior to anterior extremities terminating with a characteristically sharp and narrow tip at the extreme anterior part of the gladius. The holotype $m f$ is $95 \mathrm{~mm}$, including the tip. The maximum $m f w$ is $\sim 10 \mathrm{~mm}$ at two-thirds of the $m f$ from the posterior end. The hyperbolar zones between the median field and the lateral fields are poorly developed. The anterior sharp median field bears a prominent mid-dorsal keel as well as lateral reinforcements. The hyperbolar zone length is $\sim 25 \mathrm{~mm}$ and represents $\sim 26 \%$ of the $m f l$, including the tip. Without the tip, the hyperbolar zone length represents $\sim 30 \%$ of the $\mathrm{mfl}$. Inner asymptotes are distinct, but outer asymptotes are barely perceptible. Inner asymptotes diverge at an angle of $7^{\circ}$. The elongated tip is $14 \mathrm{~mm}$ in length, i.e., $\sim 15 \%$ of the $m f l$, and appears to be the prolongation of the mid-dorsal keel. Growth increments are well preserved on the posterior part of the gladius. Soft parts are poorly preserved on the specimen, but the outline of the mantle can be distinguished under UV light, as well as poorly preserved arm-like structures.

Etymology.-After the typical tip of this species (L., acutalis, ended by a tip).

Holotype.-MNHN.F.A50408, Hajoula (Lebanon), late Cenomanian.

Occurrence.-Hajoula, Lebanon, late Cenomanian.

Remarks.-Affinity of the holotype (Fig. 17) with the suborders Loligosepiina and Prototeuthidina can be excluded since the representatives of these two clades have a gladius with a triangular, diverging median field and without a prominent median keel. The gladius morphology of the holotype is in accordance with Naef's (1921) diagnosis of the family Palaeololiginidae (suborder Teudopseina). The specimen described here is characterized by an elongated rachis in contrast to Palaeololigo oblonga Naef, 1921, but it also differs by the presence of a tip on the anterior part of the gladius. A comparison with Marekites vinarensis Fritsch, 1910 and Styloteuthis convexa Fritsch, 1910 (both from the Turonian of Bohemia) is more problematic as the anterior extension of what resembles a rachis-like median field remains unknown for these two taxa (Fuchs and Larson, 2011b). Comparison of the soft-part anatomy with known palaeololiginids is not possible owing to the poor preservation of specimen MNHN.F.A50408. The holotype is very similar to $R$. donovani, but it slightly differs from it by its hyperbolar zone length $/ m f$ ratio $(0.3$ vs $0.23-0.26$, respectively). Additionally, illustrated specimens of $R$. donovani (Fuchs, 2006a; Fuchs and Larson, 2011a) lack a slender and narrow anterior tip. The erection of a new species is thus justified based on its diagnostic tip.

Interestingly, the typical tip of $R$. acutali $\mathrm{n}$. sp. resembles the pointed anterior extremity described in the Jurassic Teudopsis bunelii Eudes-Deslongchamps, 1835, but also in Jurassic muensterellid and palaeloliginid coleoids (Fuchs and Weis, 2010; Fuchs and Larson, 2011b). The latter are assumed to be ancestral to the genus Rachiteuthis (Fuchs and Larson, 2011b). However, Rachiteuthis donovani does not display a pointed anterior extremity or a tip (Fuchs, 2006a; Fuchs and Larson, 2011b) and a small tip is observed in the teudopseid Glyphiteuthis rhinophora (Fuchs et al., 2010a). It can be therefore hypothesized that a pointed anterior extremity or a tip is a character that may have appeared independently in different clades. The presence of a tip in $R$. acutali $\mathrm{n}$. sp. could thus be seen as a convergence with other species of the palaeololiginid/ muensterellid lineage and G. rhinophora.

\section{Phylogenetic implications}

The study of Dorateuthis syriaca specimens has allowed us to infer the phylogenetic position of this taxon relative to modern coleoids (see also Fuchs et al., 2007b; Fuchs and Larson, 2011a, 2011b). We thus detected four characters phylogenetically significant at the superorder level including one that has never been described before this work. A synthesis of these features is given in Table 1. Based on these characters, we suggest that D. syriaca (suborder Prototeuthidina) is closely related to modern vampyropods. The decabrachian-like characters are considered here as convergent with modern squids.

Number of arms.- The key feature of the Decabrachia is the presence of 10 arms with the fourth pair modified in tentacles. Supporters of the "Decabrachia Theory" usually explain the absence of preserved tentacles on gladius-bearing coleoids as reflecting the ability of modern coleoids to retract them into pockets (Young et al., 1998; Vecchione et al., 1999; Bizikov, 2008; and Donovan and Strugnell, 2010). However, no evidence of such pockets exists among the studied specimens. Additionally, to our knowledge, such pockets have not been described yet in fossil coleoids (as discussed in Fuchs and Larson, 2011b, p. 829). It can also be argued that the absence of tentacles may simply result from a preservation artifact. Kear et al. (1995) studied the influence of buoyancy on preservation probability: in coleoids that are positively buoyant after death (cuttlefishes and some oceanic squids), the tentacles easily slip out and hang loose in the water. These authors therefore considered that the prototeuthidid Plesioteuthis had tentacles, which are never preserved because of the post-mortem positive buoyancy of the individuals. However, given the absence of unambiguous tentacles in numerous published specimens of exceptionally well-preserved coleoids representing juvenile to adult stages, the invariable post-mortem tentacles loss prior to fossilization suggested by Kear et al. (1995) or the loss during ontogeny (only known in the modern decabrachian 

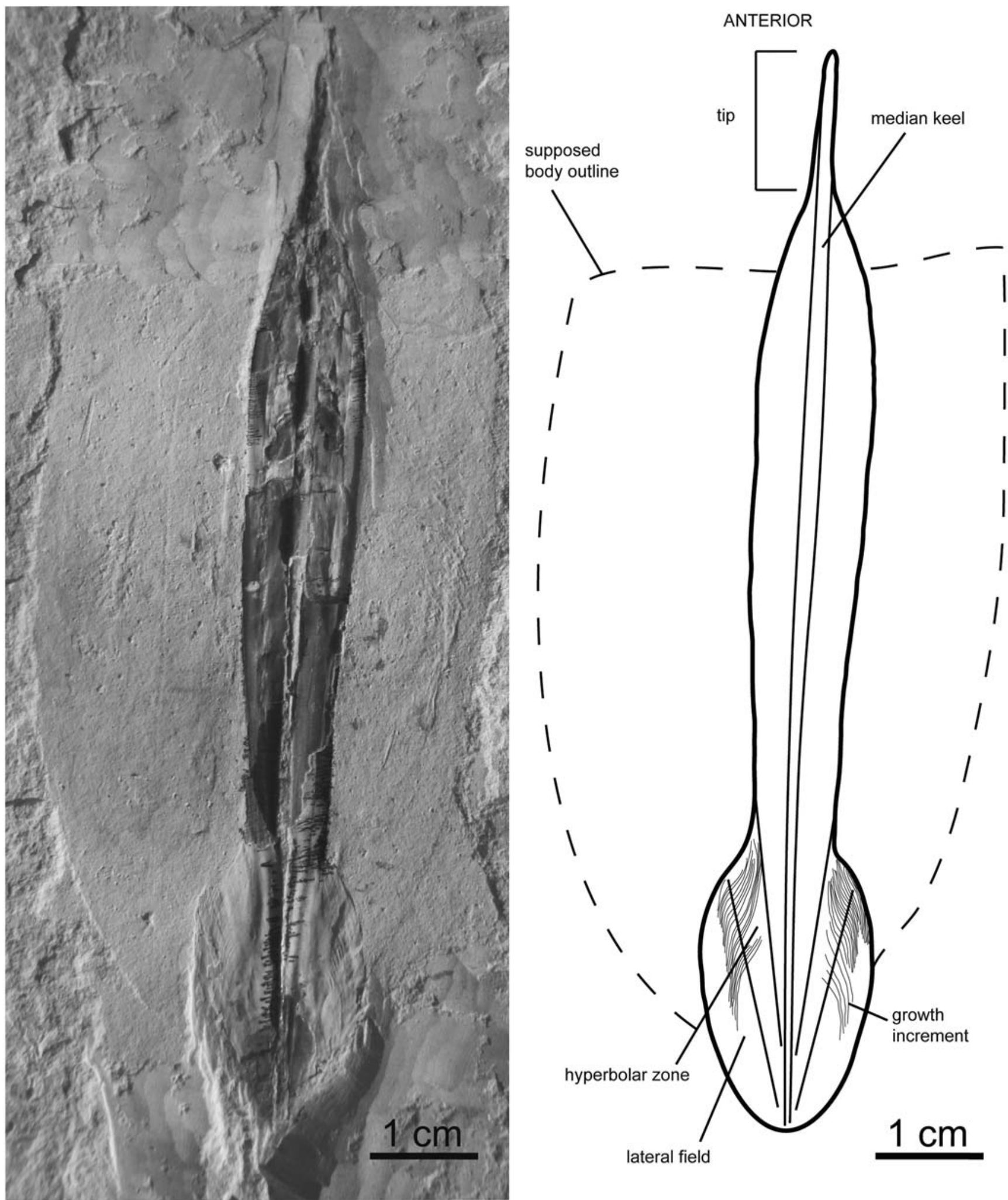

Figure 17. Gladius morphology of Rachiteuthis acutali n. sp., holotype, MNHN.F.A50408, Cenomanian, Hajoula, dorsal view. All growth increments have not been drawn.

Octopoteuthis Rüppell, 1844; Mangold et al. 1989a) appears unlikely. We therefore suggest that the absence of tentacles on the studied specimens indicates that $D$. syriaca is closely related to modern vampyropods (Table 1 ). The taxa
Mastigophora Owen, 1856 and Plesioteuthis have been described with tentacles (Vecchione et al., 1999; Naef, 1922, p. 118). However, agreeing with Haas's interpretation (2002) of only eight arms in Mastigophora, we consider that Naef (1922) 
Table 1. Synthesis of the characters with phylogenetic significance at the superorder level observed in the studied Dorateuthis syriaca specimens

\begin{tabular}{|c|c|c|}
\hline Observed $D$. syriaca characters & $\begin{array}{l}\text { Phylogenetic } \\
\text { implications } \\
\text { (this work) }\end{array}$ & $\begin{array}{c}\text { Phylogenetic } \\
\text { implications (Fuchs } \\
\text { and Larson, 2011a) }\end{array}$ \\
\hline 8 arms + absence of tentacles & Vampyropoda & Vampyropoda \\
\hline Transverse pairs of sessile suckers & Vampyropoda & - \\
\hline Presence of a crop & Vampyropoda & Vampyropoda \\
\hline Gladius similar to that of squids & Decabrachia & Decabrachia \\
\hline
\end{tabular}

misinterpreted the slightly elongated dorsal arm pair as tentacles and that the only faint traces present on Mastigophora specimens (Vecchione et al., 1999) cannot be easily interpreted as tentacles.

Suckers.-Among extant coleoids, all decabrachian species have pedunculate suckers that alternate to form oblique pairs (Young et al., 1998). Vampyropods present suckers that form oblique or transverse pairs, depending on the species. Additionally, the suckers are sessile with a wide base in incirrate octopods (Mangold et al., 1989a). Thus, in light of the transverse pairs of suckers observed in MNHN.F.A50397 (Fig. 9.4), Dorateuthis syriaca appears closely related to modern vampyropods (Table 1). Furthermore, the fact that visible suckers are sessile and cirri are absent suggests an affinity with incirrate octopods.

Modern decabrachians possess suckers with a bilateral symmetry whereas extant vampyropods have suckers with a radial symmetry (Young and Vecchione, 1996). Unfortunately, the sucker symmetry is not discernible on the studied specimens. Suckers of modern decabrachians also possess chitinous rings or teeth (or hooks). Coleoid hooks are well-known in the Lebanese Lagerstätten, but always in association with phragmocone-bearing belemnoids and never with gladiusbearing coleoids (Fuchs and Larson, 2011b, p. 829).

Within the suborder Octopoda Leach, 1818, suckers are arranged all along the arm as a single (Eledone Leach, 1817) or double (Octopus) row. Fuchs et al. (2007b) presumed a single row of suckers in the Jurassic Plesioteuthis prisca. However, Voight (1993) showed that the arrangment of suckers on octopodid arms is not a character having phylogenetic significance.

Crop.-Mangold and Young (1998) emphasized the phylogenetic value of the digestive system for the main coleoid groups. Indeed, they considered that the presence of a crop is characteristic of octopods. If the observation of a crop is validated, it would also support that Dorateuthis syriaca is closely related to modern vampyropods (Table 1).

Gladius._Donovan and Toll (1988) and Doyle et al. (1994) considered Dorateuthis syriaca and Plesioteuthis prisca as members of the superorder Decabrachia. Indeed, they suggested a close relationship with modern squids, based on a proposed homology of the gladii of extant ommastrephids and that of the genera Dorateuthis and Plesioteuthis. Similarly, Reitner and Engeser (1982) suggested a phylogenetic relationship between the Jurassic plesioteuthidid Maioteuthis and modern squids. According to Young et al. (1998), the gladius of the genus Plesioteuthis (and therefore that of Dorateuthis syriaca) is so similar to that of the ommastrephids that it indicates either a phylogenetic link or a convergence between extant squids and the genera Plesioteuthis and Dorateuthis. We agree that the gladius of D. syriaca, as well as other genera of the suborder Prototeuthidina, is very similar to that of modern squids (Mangold et al., 1989a; Boyle and Rodhouse, 2005). However, in light of the other characters we discussed previously, and in accordance with numerous authors (Bandel and Leich, 1986; Engeser and Keupp, 1999; Haas, 2002; Lukeneder and Harzhauser, 2004; Fuchs, 2006a, 2006b; Fuchs et al., 2007b; Fuchs and Larson, 2011a), it is more likely that the similarities of the gladius of prototeuthidid coleoids with that of modern squids indicate evolutionary convergences.

To summarize, we failed to find a single unequivocal decabrachian character in the specimens of Dorateuthis syriaca studied here. We consider that gladius-bearing coleoids belonging to the suborder Prototeuthidina are only superficially similar to living teuthids and that the soft-part morphology of Dorateuthis (eight arms, transverse and sessile suckers, presence of a crop; Table 1) suggests close phylogenetic relationships with the eight-armed vampyropods. We thus support the hypothesis of a vampyropod affinity as initially proposed by Bandel and Leich (1986) and later endorsed by Engeser and Keupp (1999), Haas (2002), Fuchs (2006a), and Fuchs and Larson (2011a).

\section{Conclusions}

The study of 16 gladius-bearing coleoid specimens from the Upper Cretaceous Lebanese Lagerstätten leads to a better understanding of their anatomy and of their taxonomic diversity. Four taxa of gladius-bearing coleoids were identified: the previously known Dorateuthis syriaca and Glyphiteuthis libanotica, but also Rachiteuthis acutali n. sp. and an original form of Glyphiteuthis sp. This increases the number of known Cretaceous gladius-bearing coleoid species from Lebanon from 9 to 11 .

Despite the exceptional preservation characterizing these Lebanese fossils, the anatomical and phylogenetic interpretations of soft-part characters remain difficult. However, the quality of preservation of specimens from Sahel Aalma helped us to determine a group of important soft-part characters that have a phylogenetic significance at the superorder level for $D$. syriaca. These are the absence of tentacles, the presence of a crop, and the presence of sessile and transverse pairs of suckers. Based on these characters, we conclude that $D$. syriaca (suborder Prototeuthidina) is closely related to modern vampyropods. No evidence supports a close phylogenetic relationship of the studied gladius-bearing coleoids from the Upper Cretaceous Lebanese Lagerstätten with modern decabrachians. Consequently, the evolutionary history of present-day squids and cuttlefishes still remains unclear.

\section{Acknowledgments}

We thank D. Fuchs (Berlin) who kindly shared unpublished data on D. syriaca and contributed to numerous discussions. We are grateful to S. Hageman and M. Yacobucci for their editorial 
comments, as well as the two anonymous reviewers for their constructive suggestions that improved the quality of the manuscript.

\section{References}

Agassiz, L., 1847, An introduction to the study of natural history in a series of lectures delivered in the hall of the College of Physicians and Surgeons, New York, $58 \mathrm{p}$.

Arkhipkin, A.I., Bizikov, V., and Fuchs, D., 2012, Vestigial phragmocone in the gladius points to a deepwater origin of squid (Mollusca: Cephalopoda): Deep-sea Research I, v. 61, p. 109-122.

Audo, D., and Charbonnier, S., 2013, Late Cretaceous crest-bearing shrimps from the Sahel Alma Lagerstätte of Lebanon: Acta Palaeontologica Polonica, v. 58 , p. $335-349$.

Bandel, K., and Leich, H., 1986, Jurassic Vampyromorpha (dibranchiate cephalopods): Neues Jahrbuch für Geologie und Paläontologie Monatshefte, v. 1986, p. 129-148

Bather, F.A., 1888, Shell-growth in Cephalopoda (Siphonopoda): Annals and Magazine of Natural History, v. 6, p. 421-427.

Binkhorst van den Binkhorst, J.-T., 1861, Monographie des Gastropodes et Céphalopodes de la Craie Supérieure du Limburg: Brussels, Belgium, Maastricht, the Netherlands, Verlag Muller, 44 p.

Bizikov, V.A., 2008, Evolution of the Shell in Cephalopoda: Moscow, Russia, VNIRO Publishing, $445 \mathrm{p}$.

Boettger, C.R., 1952, Die Stamme des Tierreichs in ihrer systematischen Gliederung: Abhandlungen der Braunschweigischen Wissenschaftilchen Gesellschaft, v. 4, p. 238-300.

Boletzky, S.V., 1992, Evolutionary aspects of development, life style, and reproduction mode in incirrate octopods (Mollusca, Cephalopoda): Revue Suisse de Zoologie, v. 4, p. 755-770.

Boyle, P.R., and Rodhouse, P.G., 2005, Cephalopods: Ecology and Fisheries: Oxford, UK, Blackwell Science, 452 p.

Charbonnier, S., 2009, Le Lagerstätte de La Voulte: un environnement bathyal au Jurassique: Mémoires du Muséum National d'Histoire Naturelle, v. 199. p. $1-272$.

Chun, C., 1903, Aus den Tiefen des Weltmeeres: Schilderungen von der Deutschen Tiefsee-Expedition, 549 p.

Cuvier, G., 1797, Tableau Élémentaire de 1'Histoire Naturelle des Animaux: Paris, France, Baudouin, 710 p.

Doguzhaeva, L.A., 2005, A gladius-bearing coleoid cephalopod from the Aptian of Central Russia: Mitteilungen des Geologisch-Paläontologischen Instituts, Universität Hamburg, v. 89, p. 41-48.

Doguzhaeva, L.A., and Mutvei, H., 2003, Gladius composition and ultrastructure in extinct squid-like coleoids Loligosepia, Trachyteuthis and Teudopsis: Revue de Paléobiologie, v. 22, p. 877-894.

Donovan, D.T., 1977, Evolution of the dibranchiate Cephalopoda: Symposia of the Zoological Society of London, v. 38, p. 15-48.

Donovan, D.T., and Toll, R.B., 1988, The gladius in coleoid (Cephalopoda) evolution, in Clarke, M.R., and Trueman, E.R., eds., The Mollusca. Palaeontology and Neontology of Cephalopods, Vol. 12, San Diego, California, Academic Press, p. 89-101.

Donovan, D.T., and Strugnell, J., 2010, A redescription of the fossil coleoid cephalopod genus Palaeololigo Naef, 1921 and its relationship to recent squids: Journal of Natural History, v. 44, p. 1475-1492.

Doyle, P., Donovan, D.T., and Nixon, M., 1994, Phylogeny and systematics of the Coleoida: Paleontological Contributions, v. 5, p. 1-15.

Ejel, F., and Dubertret, L., 1966, Sur l'âge précis du gisement de poissons et de crustacés de Sahel Alma (Liban): Compte Rendu Sommaire des Séances de la Société Géologique de France, v. 6, p. 353.

Engeser, T., 1988, Vampyromorpha ("Fossile Teuthiden"), in Westphal, F., ed. Fossilium Catalogus. I: Animalia, vol. 130, Amsterdam, Kugler Publications, p. $1-167$.

Engeser, T., and Reitner, J., 1985, Teuthiden aus dem Unterapt (“Töck”) von Helgoland (Schleswig-Holstein, Norddeutschland): Paläontologische Zeitschrift, v. 59, p. 245-260.

Engeser, T., and Reitner, J., 1986, Coleoidenreste aus der Oberkreide des Libanon im Staatlichen Museum für Naturkunde in Stuttgart: Stuttgarter Beiträge zur Naturkunde, Series B, v. 124, p. 1-17.

Engeser, T., and Keupp, H., 1999, Zwei neue vampyromorphe Tintenfische (Coleoidea, Cephalopoda) aus dem oberjurassischen Solnhofener Plattenkalk von Eichstätt: Archaeopteryx, v. 17, p. 21-32.

Eudes-Deslongchamps, J.-A., 1835, Mémoire sur les Teudopsides, animaux fossiles, voisins des calmars: Mémoires de la Société Linnéenne de Normandie, v. 5, p. 68-78.

Ferry, S., Merran, Y., Grosheny, D., and Mroueh, M., 2007, The Cretaceous of Lebanon in the Middle East (levant) context: Carnets de Géologie, Mémoire 2007/2 Abstract 08, p. 38-42.
Fioroni, P., 1981, Die Sonderstellung der Sepioliden, ein Vergleich der Ordnungen der rezenten Cephalopoden: Zoologische Jahrbücher, Systematik, v. 108, p. 178-228.

Fischer, J.-C., and Riou, B., 1982, Les Teuthoïdes (Cephalopoda, Dibranchiata) du Callovien Inférieur de la Voulte-sur-Rhône (Ardèche, France): Annales de Paléontologie, v. 68, p. 295-325.

Forey, P.L., Yi, L., Patterson, C., and Davies, C.E., 2003, Fossil fishes from the Cenomanian (Upper Cretaceous) of Namoura, Lebanon: Journal of Systematic Palaeontology, v. 1, p. 227-330.

Fraas, O., 1878, Geologisches aus dem Libanon: Jahreshefte des Vereins für vaterländische Naturkunde in Württemberg, v. 34, p. 257-391.

Fritsch, A., 1910, Neue Cephalopoden aus der Kreideformation Boehmens, in Fritsch, A., ed., Miscellanea Palaeontologica II. Volume Mesozoica: Prague, Czech Republic, p. 12-15.

Fuchs, D., 2006a, Diversity, taxonomy and morphology of vampyropod coleoids (Cephalopoda) from the Upper Cretaceous of Lebanon: Memorie della Società Italiana di Scienze Naturali et del Museo Civico di Storia Naturale di Milano, v. 34, p. 1-28.

Fuchs, D., 2006b, Fossil erhaltungsfähige Merkmalskomplexe der Coleoidea (Cephalopoda) und ihre phylogenetische Bedeutung: Berliner Paläobiologische Abhandlungen, v. 8, p. 1-115.

Fuchs, D., 2007, Coleoid cephalopods from the Plattenkalks of the late Jurassic of southern Germany and the late Cretaceous of Lebanon-a faunal comparison: Neues Jahrbuch für Geologie und Paläontologie Abhandlungen, v. 245 , p. $59-69$.

Fuchs, D., 2009, Octobrachia-a diphyletic taxon?: Berliner Paläobiologische Abhandlungen, v. 10, p. 182-192.

Fuchs, D., and Weis, R., 2008, Taxonomy, morphology and phylogeny of Lower Jurassic loligosepiid coleoids (Cephalopoda): Neues Jahrbuch für Geologie und Paläontologie Abhandlungen, v. 249, p. 93-112.

Fuchs, D., and Weis, R., 2009, A new Cenomanian (late Cretaceous) coleoid (Cephalopoda) from Hâdjoula, Lebanon: Fossil Record, v. 12, p. $175-181$.

Fuchs, D., and Weis, R., 2010, Taxonomy, morphology and phylogeny of Lower Jurassic teudopseid coleoids (Cephalopoda): Neues Jahrbuch für Geologie und Paläontologie Abhandlungen, v. 257, p. 351-366.

Fuchs, D., and Larson, N., 2011a, Diversity, morphology and phylogeny of coleoid cephalopods from the Upper Cretaceous Plattenkalks of Lebanonpart I: Prototeuthidina: Journal of Paleontology, v. 85, p. 234-249.

Fuchs, D., and Larson, N., 2011b, Diversity, morphology and phylogeny of coleoid cephalopods from the Upper Cretaceous Plattenkalks of Lebanonpart II: Teudopseina: Journal of Paleontology, v. 85, p. 815-834.

Fuchs, D., Keupp, H., and Engeser, T., 2003, New records of soft parts of Muensterella scutellaris Muenster, 1842 (Coleoidea) from the late Jurassic Plattenkalks of Eichstätt and their significance for octobrachian relationships: Berliner Paläobiologische Abhandlungen, v. 3, p. 101-111.

Fuchs, D., Engeser, T., and Keupp, H., 2007a, Gladius shape variation in coleoid cephalopod Trachyteuthis from the upper Jurassic Nusplingen and Solnhofen Plattenkalks: Acta Palaeontologica Polonica, v. 52, p. 575-589.

Fuchs, D., Klinghammer, A., and Keupp, H., 2007b, Taxonomy, morphology and phylogeny of plesioteuthidid coleoids from the Upper Jurassic (Tithonian) Plattenkalks of Solnhofen: Neues Jahrbuch für Geologie und Paläontologie Abhandlungen, v. 245, p. 239-252.

Fuchs, D., Bracchi, G., and Weis, R., 2009, New records of octopods (Cephalopoda: Coleoidea) from the late Cretaceous (upper Cenomanian) of Hakel and Hadjoula (Lebanon): Palaeontology, v. 52, p. 65-81.

Fuchs, D., Stinnesbeck, W., Ifrim, C., Giersch, S., Gutierrez, J.M.P., and Frey, E., 2010a, Glyphiteuthis rhinophora n. sp., a trachyteuthidid (Coleoidea, Cephalopoda) from the cenomanian (late cretaceous) of Mexico: Paläontologische Zeitschrift, v. 84, p. 523-532.

Fuchs, D., Boletzky, S.V., and Tischlinger, H., 2010b, New evidence of functional suckers in belemnoid coleoids (Cephalopoda) weakens support for the 'Neocoleoidea' concept: Journal of Molluscan Studies, v. 76, p. 404-406.

Fuchs, D., Keupp, H., and Wiese, F., 2012, Protoconch morphology of Conoteuthis (Diplobelida, Coleoidea) and its implications on the presumed origin of the Sepiida: Cretaceous Research, v. 34, p. 200-207.

Gayet, M., 1980, Contribution à l'étude anatomique et systématique des poissons Cénomaniens du Liban anciennement placés dans les Acanthoptérygiens: Mémoires du Muséum National d'Histoire Naturelle, Série C, Sciences de la Terre, v. 44, p. 1-149.

Haas, W., 1997, Der ablauf der entwicklungsgeschichte der Decabrachia (Cephalopoda, Coleoidea): Palaeontographica, Abteilung A, v. 254, p. 63-81.

Haas, W., 2002, The evolutionary history of the eight-armed Coleoidea, in Summesberger, H., Histon, K., and Daurer, A., eds., Cephalopods-Present \& Past: Vienna, Austria, Abhandlungen der Geologischen Bundesanstalt, v. 57, p. $341-351$

Haas, W., 2003, Trends in the evolution of the Decabrachia: Berliner Paläobiologische Abhandlungen, v. 3, p. 113-129. 
Jeletzky, J.A., 1965, Taxonomy and phylogeny of fossil Coleoidea (= Dibranchiata): Geological Survey of Canada, Papers 65-2, 42, p. 76-78.

Jeletzky, J.A., 1966, Comparative morphology, phylogeny and classification of fossil Coleoidea: Paleontological Contributions, University of Kansas, Mollusca, v. 7, p. 1-166.

Kear, A., Briggs, D.E.G., and Donovan, D.T., 1995, Decay and fossilization of non-mineralized tissue in coleoid cephalopods: Palaeontology, v. 38, p. $105-131$.

Klinghardt, F., 1943, Vergleichende untersuchungen über tintenfische und belemnitenähnliche weichtiere: Sitzungsberichte der Gesellschaft naturforschender Freunde in Berlin, v. 1942, p. 5-17.

Kolbe, H.J., 1888, Zur Kenntnis der insektenbohrgänge in fossilen hölzern: Zeitschrift der Deutschen Geologischen Gesellschaft, v. 40, p. 131-137.

Kostak, M., 2002, Teuthoidea from the Bohemian Cretaceous Basin (Czech Republik)-a critical review, in Summesberger, H., Histon, K., and Daurer, A., eds., Cephalopods-Present \& Past, Abhandlungen der Geologischen Bundesanstalt, v. 57, p. 359-369.

Kretzoi, M., 1942, Necroteuthis n. gen. (ceph. dibr. Necroteuthidae n. f.) aus dem oligozän von Budapest und das system der Dibranchiata: Földtani Közlöny, v. 72, p. 124-138.

Kröger, B., Vinther, J., and Fuchs, D., 2011, Cephalopod origin and evolution: a congruent picture emerging from fossils, development and molecules: Bioessays, 1-12.

Lamarck, J.B., 1798, Extrait d'un mémoire sur le genre de la Sèche, du Calmar et du Poulpe, vulgairement nommés Polypes de Mer: Bulletin des Sciences par la Société Philomatique de Paris, v. 5, p. 129-131.

Larson, N.L., Morton, R.W., Larson, P.L., and Bergmann, U., 2010, A new look at fossil cephalopods, in Tanabe, K., Shigeta, Y., Sasaki, T., and Hirano, H., eds., Cephalopods—Present \& Past: Tokyo, Japan, Tokai University Press, p. 303-314.

Leach, W.E., 1817, Synopsis of the orders, families, and genera of the class Cephalopoda: The Zoological Miscellany, being descriptions of new or interesting animals, v. 3, p. 137-141

Leach, W.E., 1818, Sur plusieurs espèces nouvelles de la classe des cephalopodes et sur une nouvelle distribution systematique des ordres, familles et genres de cette classe: Journal de Physique, de Chimie et d'Histoire Naturelle, v. 86, p. 393-396.

Lennier, G., 1866, Notes pour servir à l'étude de la paléontologie Normande: Bulletin de la Société de Géologie de Normandie, v. 11, p. 21-31.

Lichtenstein, H.C., 1818, Von den sepien mit krallen: Isis, oder Encyclopädische Zeitung, v. 9, p. 1591-1592.

Linnaeus, C., 1758, Systema Naturæ per Regna Tria Naturæ, Secundum Classes, Ordines, Genera, Species, Cum Characteribus, Differentiis, Synonymis, Locis: Stockholm, Sweden, Laurentius Salvius, 824 p.

Lukeneder, A., and Harzhauser, M., 2004, The Cretaceous coleoid Dorateuthis syriaca Woodward: morphology, feeding habits and phylogenetic implications: Annalen des Naturhistorischen Museums Wien, v. 106, p. 1-14.

Mangold, K.M., and Bidder, A.M., 1989a, L'appareil digestif et la digestion, in Grassé, P.-P., ed., Traité de Zoologie: Anatomie, Systématique, Biologie: Céphalopodes, Tome V, Fascicule 4, p. 321-373.

Mangold, K.M., and Bidder, A.M., 1989b, Appareils respiratoire et circulatoire: respiration et circulation, in Grassé, P.-P., ed., Traité de Zoologie: Anatomie, Systématique, Biologie: Céphalopodes, Tome V, Fascicule 4, p. 387-434.

Mangold, K.M., and Young, R.E., 1998, The systematic value of the digestive organs, in Voss, N.A., Vecchione, M., Toll, R., and Sweeney, M., eds., Systematics and Biogeography of Cephalopods, Smithonian Contributions to Zoology, v. 1, p. 21-30.

Mangold, K.M., Bidder, A.M., and Portmann, A., 1989a, Organisation générale des céphalopodes, in Grassé, P.-P., ed., Traité de Zoologie: Anatomie, Systématique, Biologie: Céphalopodes, Tome V, Fascicule 4, p. 7-69.

Mangold, K.M., Bidder, A.M., and Portmann, A., 1989b, Structures cutanées, in Grassé, P.-P., ed., Traité de Zoologie: Anatomie, Systématique, Biologie: Céphalopodes, Tome V, Fascicule 4, p. 121-162.

Marck, W.Von Der, 1873, Neue Beiträge zur kenntnis der fossilen fische und anderer thierreste aus der jüngsten kreide Westfalens, sowie aufzählung sämtlicher seither in der Westfälischen kreide aufgefundenen fischreste: Palaeontographica, v. 22, p. 55-74.

Meister, C., 1993, Les collections du département de géologie et de paléontologie du Musée d'Histoire Naturelle de Genève, La collection des poissons du Liban: Revue de Paléobiologie, v. 12, p. 301-310.

Meyer, H., 1846, Mitteilungen an Prof. Bronn Gerichtet: Neues Jahrbuch für Mineralogie, Geognosieund Geologie und Petrefactenkunde, v. 1846 , p. 596-599.

Münster, G. Graf zu, 1843, Die schalenlosen cephalopoden im unteren Jura, den Lias-schiefern von Franken und Schwaben: Beiträge zur Petrefaktenkunde, v. 6 , p. 57-77.

Münster, G. Graf zu, 1846, Ueber die schalenlosen cephalopoden des oberen juragebirges, der lithographischen kalkschiefern von Bayern: Beiträge zur Petrefaktenkunde, v. 7, p. 51-65.
Naef, A., 1921-1923, Fauna e flora del Golfo di Napoli, monograph no. 35, Cephalopoda: Berlin, Germany, Friedländer und Sohn, 917 p.

Naef, A., 1922, Die fossilen tintenfische-eine paläozoologische monographie: Jena, Germany, Fischerverlag, G. Fischer, 322 p.

Nixon, M., 1998, Cephalic cartilage of Cephalopoda, in Voss, N.A., Vecchione, M., Toll, R., and Sweeney, M., eds., Systematics and Biogeography of Cephalopods: Smithonian Contributions to Zoology, v. 1, p. 31-38.

Norman, M.D., 1992, Ameloctopus littoralis gen. et sp. nov (Cephalopoda, Octopodidae, a new shallow-water Octopus from tropical Australian waters: Invertebrate Taxonomy, v. 6, p. 567-582.

Owen, R., 1856, Descriptive Catalogue of the Fossil Organic Remains of Invertebrata: Museum of the Royal College of Surgeons of England, $260 \mathrm{p}$.

Philip, J., Babinot, J.F., Tronchetti, G., Fourcade, E., Ricou, L.E., Guiaud, R., Bellion, Y., Herbin, J.P., Combes, P.E., Conee, J.J., and Dercourt, J., 1993, Late Cenomanian palaeoenvironments (94-92Ma), in Dercourt, J., Ricou, L.E., and Vrielynck, B., eds., Atlas Tethys Palaeoenvironmental Maps: Paris, France, Gauthier-Villarss.

Quenstedt, F.A., 1849, Petrefactenkunde Deutschlands, 1. Abteilung, 1. Band, Cephalopoden: Tübingen, Germany, Verlag Fues, 581 p.

Regteren Altena, C.O.V., 1949, Teyler's Museum systematic catalogue of the palaeontological collection-sixth supplement (Teuthoidea): Archives du Musée Teyler, v. 3, p. 53-62.

Reitner, J., 2009, Preserved gill remains in Phragmoteuthis conocauda (Quenstedt, 1846-1849) (Toarcian, southern western Germany): Berliner Paläobiologische Abhandlungen, v. 10, p. 289-295.

Reitner, J., and Engeser, T., 1982, Teuthiden aus dem barrême der insel maio (kapverdische inseln): Paläontologische Zeitschrift, v. 56, p. 209-216.

Reuss, A.E., 1854, Loliginidenreste in der kreideformation: Abhandlungen der königlichen böhmischen Gesellschaft für Wissenschaften, v. 5, p. 29-32.

Riegraf, W., 1987, Plesioteuthis arcuata Von Der Marck 1873 (Cephalopoda Teuthida) from the Campanian (late Cretaceous) of Westfalia (NW Germany): Münsterische Forschung zur Geologie und Paläontologie, v. 66, p. $95-110$.

Rioult, M., 1962, Un calmar fossile du Cénomanien de Haute-Normandie: Bulletin de la Société Géologique de Normandie, v. 52, p. 10-13.

Roemer, F.A., 1852, Die Kreidebildungen von Texas und Ihre Organischen Einschüsse: Germany, Adolf Marcus, Bonn, 100 p.

Roger, J., 1946, Les invertébrés des couches à poissons du Crétacé Supérieur du Liban: Mémoires de la Société Géologique de France, v. 51, p. 1-92.

Roger, J., 1952, Sous-classes des Dibranchiata Owen 1836, in Piveteau, J., ed., Traité de Paléontologie, v. 2, Paris, France, Masson, p. 689-755.

Roman, F., 1928, Callovien Inférieur-horizon à nodules de crustacés et poissons, in Sayn, G., and Roman, F., eds., Monographie Stratigraphique et Paléontologique du Jurassique Moyen de La Voulte-sur-Rhône: Travaux du Laboratoire de Géologie de la Faculté des Sciences de Lyon, v. 13, p. $102-115$.

Rüppel, E., 1829, Abbildung und Beschreibung einiger neuer oder wenig bekannten Versteinerungen aus der Kalkschieferformation von Solnhofen: Frankfurt, Germany, Brönner Verlag, $12 \mathrm{p}$.

Rüppel, E., 1844, Intorno ad alcuni cefalopodi del mare di Messina: Giornale del Gabinetto Letteràrio di Messina, v. 27-28, p. 129-135.

Starobogatov, Y.I., 1983, The system of the Cephalopoda, in Starobogatov, Y.I., and Nesis, K.N., eds., Taxonomy and ecology of Cephalopoda: Leningrad, USSR, Zoological Institute, USSR Academy of Sciences, p. 4-7.

Stoliczka, F., 1863-1866, Ammonitidae, with revision of the Nautilidae, in Blanford, H.F., and Stoliczka, F., eds., The Fossil Cephalopoda of the Cretaceous Rocks of Southern India: Memoirs of the Geological Survey of India, Palaeontologia Indica (Series 1 \& 3), v. 1, p. 41-216.

Strugnell, J., Norman, M., Jackson, J., Drummond, A.J., and Cooper, A., 2005 , Molecular phylogeny of coleoid cephalopods (Mollusca: Cephalopoda) using a multigene approach; the effect of portioning on resolving phylogenies in a Bayesian framework: Molecular Phylogenetics and Evolution, v. 37, p. $426-441$.

Strugnell, J., Jackson, J., Drummond, A.J., and Cooper, A., 2006, Divergence times estimates for major cephalopod groups: evidence from multiple genes: Cladistics, v. 22, p. 89-96.

Sweeney, M.J., and Roper, C.F.E., 1998, Classification, type localities, and type repositories of recent Cephalopoda: Smithsonian Contribution to Zoology, v. 586, p. 561-599.

Teichert, C., 1988, Main features of cephalopod evolution, in Clarke, M.R., and Trueman, E.R., eds., The Mollusca: Paleontology and Neontology of Cephalopods, v. 12, p. 11-79.

Toll, R.B., 1998, The gladius in teuthoid systematics, in Voss, N.A., Vecchione, M., Toll, R., and Sweeney, M., eds., Systematics and Biogeography of Cephalopods; Smithonian Contributions to Zoology, v. 1, p. 55-67.

Vecchione, M., Young, R.E., Donovan, D.T., and Rodhouse, P.G., 1999 Reevaluation of coleoid cephalopod relationships based on modified arms in the Jurassic coleoid Mastigophora: Lethaia, v. 32, p. 113-118. 
Voight, J.R., 1993, The arrangement of suckers on octopodid (incirrata) arms as a continuous character: Malacologia, v. 35, p. 351-359.

Wagner, A., 1859, Revision der bisherigen systematischen bestimmungen der überreste von nackten dintenfischen aus dem süddeutschen juragebirge: Gelehrte Anzeigen der Koöniglichen Bayerischen Akademie der Wissenschaften, v. 34, p. 273-278.

Wilby, P.R., Hudson, J.D., Clements, R.G., and Hollingworth, N.T.J., 2004, Taphonomy and origin of an accumulate of soft-bodied cephalopods in the Oxford Clay Formation (Jurassic, England): Palaeontology, v. 45, p. 1159-1180.

Whiteaves, J.F., 1897, On some remains of a sepia-like cuttlefish from the Cretaceous rocks of the south Saskatchewan: The Canadian Record of Science, v. 7, p. 459-462.

Woodward, H., 1883, On a new genus of fossil "calamary" from the Cretaceous formation of Sahel Alma, near Beirût, Lebanon, Syria: Geological Magazine, new series, v. 10, p. 1-5.
Woodward, H., 1896, On a fossil octopus (Calais newboldi, J. de C. Sby. MS.) from the Cretaceous of the Lebanon: Quaternary Journal of the Geological Society of London, v. 52, p. 229-234.

Young, R.E., and Vecchione, M., 1996, Analysis of morphology to determine primary sister-taxon relationships within coleoid cephalopods: American Malacological Bulletin, v. 12, p. 91-112.

Young, R.E., Vecchione, M., and Donovan, D.T., 1998, The evolution of cephalopods and their present biodiversity and ecology: South Africa Journal of Marine Science, v. 20, p. 393-420.

Zittel, K.A., 1895, Mollusca. Grundzüge der Palaentologie (Palaeozoologie): München, Leibzig, Germany, Verlag von Oldenbourg, p. 386-435.

Accepted 27 May 2014 